\title{
LAS MEMORIAS DE UN SETENTÓN DE MESONERO ROMANOS EN EL MARCO DE LA AUTOBIOGRAFÍA ESPAÑOLA DECIMONÓNICA
}

\author{
Fernando DURÁN LÓPEZ \\ Universidad de Cádiz
}

\section{LA AUTOBIOGRAFÍA EN 1878}

Las Memorias de un setentón de Ramón de Mesonero Romanos (1803-1882) son una obra importante y bien conocida de la literatura decimonónica española, que se ha venido reeditando regularmente desde su primera aparición en las páginas de La Ilustración Española y Americana en marzo de 1878 y hasta la actualidad', y que en buena medida ha contribuido a sedimentar en la memoria colectiva una imagen de la vida española durante la primera mitad del XIX. Sin embargo, el contenido de su evocación histórica y el perfil de su autor como uno de los tres o cuatro grandes escritores costumbristas del siglo han acaparado la atención de la crítica, oscureciendo otras perspectivas de análisis. Así, mientras que es habitual estudiar la relación de las Memorias con los artículos de costumbres del propio Mesonero y con la novela galdosiana, su carácter autobiográfico ha sido dejado de lado.

' Un par de artículos publicados en 1876 y 1877 los aprovechó Mesonero en las Memorias, cuyo texto empezó a aparecer regularmente en la revista entre el 22-III-1878 y el 30-XI-1879 a 10 largo de treinta y una entregas; el texto se recogió en volumen, con cambios, en 1880 y de nuevo corregido en 1881. Ha habido ediciones al menos en 1924-1926, 1961, 1967, 1975, 1982, 1994 y 1997. Pueden verse los detalles bibliográficos en Durán López (1997, $\mathrm{n}^{\circ} 293$ ) y en la edición preparada por José Escobar y Joaquín Álvarez Barrientos (Mesonero 1994, págs. 71, 75-83), que es la que seguiré aquí, única con carácter crítico, que coteja las sucesivas versiones y anota sus fuentes. 
El problema no es nuevo ni se reduce a este caso, sino que se trata de una carencia general: el desconocimiento crítico de la autobiografía en España ha estado tan extendido que las pocas piezas que han alcanzado la categoría de clásicos o cierto éxito editorial -Teresa de Ávila, Torres Villarroel, Godoy, Alcalá Galiano, Mesonero, Zorrilla...- no se contextualizan dentro de su género porque los estudiosos no suelen disponer de una perspectiva del mismo que permita una adecuada valoración. En las últimas décadas, esa carencia se ha ido reparando y obras como las de Santa Teresa y Torres han recibido ya muchos y variados acercamientos desde el lado de la literatura del yo. En el caso de los textos del XIX el problema era más agudo, porque la producción es mucho más rica, más variada, más desconocida y, por tanto, más difícil de abordar. Las diferentes panorámicas de Anna Caballé (1990, 1991, 1995 y 1998) y James Fernández (1991 y 1992), que insistieron particularmente en el caso de Mesonero, pusieron la primera base seria para esta tarea, completada por otros críticos con ya un buen número de estudios particulares sobre obras y autores que, sin embargo, apenas han incluido al autor madrileño entre sus preferencias ${ }^{2}$.

Mi propósito es, por tanto, establecer la importancia de las Memorias de un setentón dentro de la evolución de la autobiografía española en los siglos XIX y $\mathrm{XX}$, tratar de indagar sobre su aportación, sus raíces y su papel en la consolidación de ese género literario, prescindiendo de referencias que no provengan del territorio de la autobiografía. Trataré así de contrastar afirmaciones como la de José Escobar y Joaquín Álvarez Barrientos de que son éstas las primeras que institucionalizan en la historia literaria española la determinación genérica «memorias», ya que se echaba de menos -dicen- «un modelo genérico instituido con que configurar la narración autobiográfica como una de las exigencias discursivas de la modernidad» (en Mesonero 1994, pág. 63). Anna Caballé, con un conocimiento más exhaustivo del tema, coincide en situar un momento crucial del género en torno a la obra del madrileño: «el siglo XIX ofrece un ritmo discontinuo pero de indudable coherencia: desde 1811 (cuando se edita la Memoria de Jovellanos) y hasta 1899 (fecha en que empiezan a publicarse las plúmbeas Memorias de Nicolás Estévanez), la producción autobiográfica es ininterrumpida. No obstante, el auge del género se sitúa en torno a los últimos decenios del siglo entre 1870 y 1890 , aproximadamente. Pues entre estas dos fechas se reparten las obras más

${ }^{2}$ Una excepción la suponen el artículo de José Escobar (1993) y la excelente edición de las Memorias hecha por éste mismo y por Joaquín Álvarez Barrientos, donde se efectúa un meritorio esfuerzo por reconstruir los lazos de Mesonero con otras autobiografías; no obstante, el juego de referencias a textos autobiográficos españoles sigue siendo demasiado escaso para obtener conclusiones sólidas, lo que contrasta con el mucho mayor espacio consagrado a desentrañar la evolución que supone para Mesonero este libro respecto a sus colecciones de cuadros de costumbres. 
clásicas y representativas del memorialismo decimonónico: Alcalá Galiano, Patricio de la Escosura, Julio Nombela, Zorrilla, Mesonero Romanos y un largo etcétera de nombres conocidos» (Caballé 1990, pág. 56). Un gran año sería 1880, con la aparición de las obras de Mesonero Romanos, Zorrilla y otros: la investigadora no duda en atribuir al éxito del Setentón la gran eclosión de la autobiografía a fines de siglo.

Pero la atribución de un papel tan importante a un único libro merece ser desentrañada con más pormenores y matices: para ello es preciso disponer de un conocimiento firme sobre los textos españoles y sobre las diferentes líneas de evolución que administran el auge de la escritura personal desde el último cuarto del XIX, de lo contrario se pueden cometer errores como afirmar que en las Memorias de Emilio Gutiérrez-Gamero, publicadas entre 1925-1934, el autor «...se retrata como testigo de los muchos acontecimientos políticos de la etapa de la Restauración, anticipando un tipo de relatos autobiográficos, para los que los sucesos históricos y políticos, a lo largo del siglo, han actuado con frecuencia como revulsivo y estímulo de la memoria» (Blasco 1993, pág. 114, cursiva mía). Trataré de demostrar en este artículo que Gutiérrez-Gamero no es más que otro de los muchos herederos que dejó el Setentón madrileño y que no anticipa, sino que continúa, ese tipo de relato autobiográfico. Para completar el cuadro de referencias que prueben tal aseveración, me serviré principalmente del catálogo del género en España que he publicado en fecha reciente (Durán López 1997 y 1999) y que proporciona una base para iniciar un estudio más completo del tema.

A la hora de abordar la influencia de Mesonero Romanos en la autobiografía en España, hay que matizar el contexto en que esto se produce. Como creo haber mostrado en mis trabajos citados, bajo esa rúbrica de autobiografía no tenemos un contenido homogéneo, sino que agrupamos tipos de discurso bien diferentes y formas de identidad personal -concepciones del yo- a menudo no sólo distintas sino antitéticas. En algún momento se puede deducir de frases en exceso grandilocuentes la errónea idea de que es Mesonero quien crea o aclimata la autobiografía en España. Eso no es así: cuando en 1878 el escritor madrileño se pone a dar a la imprenta sus Memorias de un setentón, tanto él como los demás lectores españoles disponían ya de otros modelos de autobiografía en el mercado editorial. Es decir, había otras posibilidades de institucionalización del discurso autobiográfico, que fueron abiertas por autores anteriores, con diferente fortuna; la misma fórmula que haría triunfar Mesonero no carecía, como se dirá, de antecedentes. Pero de momento veamos cuáles eran las alternativas de 
discurso del yo entre las que podía elegir un escritor o un lector a la altura de $1878^{3}$.

Mesonero rechaza, por ejemplo, el modelo que pudieran haberle ofrecido contemporáneos suyos como Antonio María García Blanco (1800-1889) con su Biografía de D. Antonio María García Blanco, escrita por sí mismo, o sea Historia compendiada de los conocimientos hebreos en España (1869, publicada previamente en 1851), Fernando de Castro (1814-1874) con su Memoria testamentaria (1874) y Gumersindo de Azcárate (1840-1917) con su Minuta de un testamento (1876). Se trata de obras de krausistas y católicos liberales que tienden a analizar sus vidas desde una perspectiva moral y espiritual, centrándose en el yo y con un fuerte componente crítico y heterodoxo en materia política y religiosa. Tal exhibición de autoconciencia sin duda se le antojaba impúdica a Mesonero e iba contra las directrices usuales de la pacata literatura personal española, pero era una realidad presente en la cultura del país en aquel tiempo.

Otro modelo alternativo de autobiografía por el que un escritor podría haber optado en la década de 1870 es el que vemos en la exitosa obra del novelista Enrique Pérez Escrich (1829-1897), El frac azul. Episodios de un joven flaco (1864, ampliado en sucesivas ediciones hasta la cuarta de 1875), donde el autor recurre a todos los trucos de la construcción novelística para realizar una emocionada autobiografía personal contando en tercera persona la juventud como joven escritor bohemio de Elías (él mismo, usando su nombre real). Un procedimiento parecido empleó Patricio de la Escosura (1807-1878), cuando en 1868 dio a luz en la Revista de España y en seguida en volumen sus Memorias de un coronel retirado. Novela original, en realidad una novela autobiográfica o autobiografía novelada, según prefiramos denominarla. El protagonista adopta el nombre de Lescura, que apenas oculta el apellido real del autor, para trazar a partir de la ficción de un manuscrito que le fue entregado por un amigo una historia de la vida de Escosura a partir de 1830, narrando las peripecias políticas y militares de su alocada juventud, y sus apasionados amores. Mesonero, que quiso sin éxito ser novelista, está también en las antípodas de un discurso personal tan literaturizado y, sobre todo, tan egocéntrico. De haber sido personaje de novela, estaba destinado a identificarse con el narrador, como en las Memorias de un setentón, y no

${ }^{3}$ En mis trabajos ya citados se pueden encontrar las referencias detalladas de casi todos los textos que cito, por lo que sólo mencionaré título y año de cada obra. Me limito a obras impresas, únicas que en el XIX establecen una influencia real sobre el público, pero también han de tenerse en cuenta las muchas que quedaron inéditas, incompletas o se publicaron muy tardíamente. 
tanto con el protagonista: Pérez Escrich y Escosura, en diferentes grados en cada caso, fueron las dos cosas a un tiempo ${ }^{4}$.

Pero quizá el tipo de relato autobiográfico más sólidamente enraizado en el panorama editorial español del XIX venía siendo desde principios de siglo el de las memorias políticas, militares o diplomáticas, obras extensas y casi siempre minuciosas que desgranan toda una carrera pública o una parte de ella, a modo de testimonio histórico y casi siempre también de defensa personal. Los numerosos textos impresos antes de las Memorias de un setentón se escalonan a lo largo de varias décadas: Manuel Godoy (1836), el Marqués de Miraflores (sucesivas entregas en 1843-1844, 1865, 1873), Manuel Llauder (1844), Rafael Maroto (1846), José Nicolás de Azara (1847, original de los últimos años del XVIII), el Marqués de Labrador (1849), Francisco Espoz y Mina (1851-1852), Francisco de Copóns (1858, originales de 1818 y 1826), José del Castillo y Ayensa (1859), entre otross.

Este tipo de narración autobiográfica estaba ya plenamente institucionalizado en la cultura española y no dejará de crecer, sin que haya que atribuir un papel esencial a Mesonero en ese crecimiento, aunque en muchos casos sí proyectó su influjo sobre tales escritos. Aunque se trata de una fórmula bastante diferente, su ejemplo pudo servir para que La Ilustración Española y Americana publicase entre 1880-1881 la obra quizá más característica de esa modalidad en la Restauración, Mis memorias íntimas de Fernando Fernández de Córdoba (en libro en 1886-1889). También la publicación tardía de las Memorias de Alcalá Galiano en 1886 y las de José García de León Pizarro en 1894-1897 (original de 1833) puede deberse a la moda autobiográfica a la que Mesonero tanto contribuyó. En cualquier caso, es ése el modelo de memorias que Mesonero Romanos tiene en mente al elaborar sus Memorias de un setentón, no para reproducirlo,

${ }^{4}$ Joaquín Álvarez Barrientos (1995) ha desarrollado la relación de las Memorias de un setentón con la novela, pero deja bien claro que cualquier proximidad entre Mesonero y ese otro género se refiere a la novela histórica y de costumbres contemporáneas, al estilo de Galdós. Pero también había otros modelos novelescos en vigor, como los seguidos por Pérez Escrich y Escosura, que practican un tipo de narración romántica, melodramática y folletinesca, centrada en un héroe al que suceden toda clase de aventuras. En la novela, como en la autobiografía, no se puede llegar a ninguna conclusión válida si se toman como bloques homogéneos que caminan por una sola dirección.

${ }^{5}$ Muchos de estos libros tienen un destacado componente autojustificativo y polémico, pero su desarrollo va más allá de la simple defensa circunstancial. Son mucho más frecuentes las memorias que denomino justificativas, piezas más breves y coyunturales sobre asuntos concretos de los que el autor, en caliente y con agresividad, se defiende. En mi catálogo puede verse una muestra representativa de esas obras, sobre todo a partir de 1808 , y he tratado de ofrecer una caracterización más completa de ese subgénero en mi edición de uno de sus mejores productos, las Memorias de Manuel José Quintana (Durán López 1996, págs. 21-45). 
sino para apartarse conscientemente de él según un criterio que distingue la gran historia, política y militar, que aparece en obras como las de Godoy o Alcalá Galiano, de la pequeña historia, cotidiana y sencilla, más social que política, más impersonal que egocéntrica, que él pretenderá evocar en sus recuerdos.

El hecho que quiero destacar, en suma, es que en los años en que Mesonero gesta y publica sus memorias, en el mercado editorial español están presentes varios formatos diferentes de autobiografía que, con mejor o peor fortuna, determinan un desarrollo del género que no sólo hay que asociar al célebre costumbrista madrileño. ¿Cuál es, entonces, el valor de sus aportaciones a la autobiografía española? Mesonero, a mi juicio, consuma la evolución del memorialismo hacia una fórmula muy concreta de escritura autobiográfica, que aunque venía de antes arraiga gracias a él con inusitado vigor en la literatura española. Las Memorias de un setentón operan como modelo de referencia y principal vía de difusión para esa clase de escritos, y sobre ellos ejerce una perdurable influencia. En buena parte gracias al Curioso Parlante esa modalidad autobiográfica adquiere protagonismo y acapara un sustancial segmento de la producción de memorias en España, al tiempo que proyecta su influencia en otros géneros literarios afines. Eso desde luego no implica que las otras fórmulas autobiográficas desaparezcan ni sean absorbidas por la de Mesonero. A describir ésta dedico el siguiente apartado.

\section{LA AUTOBIOGRAFÍA SEGÚN MESONERO ROMANOS}

[...] la obra no tiene continuidad ni coherencia interna: no es más que una colección de estampas que fácilmente recuerdan al castizo autor de las Escenas matritenses [...]. En este sentido, es frecuente el detalle arqueológico o la noticia curiosa, aunque esta abundancia de referencias no se acompañe de una indagación acerca de su sentido (que es lo que cuenta, al fin y al cabo). Todo son inspirados dramas, elegantes plumas y acendrados patriotismos; nada que revele al lector actual la complejidad de la naturaleza humana, el policromismo de su diversidad (Caballé 1991, pág. 147).

Este riguroso juicio de Anna Caballé no anda desencaminado, valoraciones subjetivas aparte, aunque peca de demasiado rotundo. Si en la escasez de sentido crítico y de hondura analítica por parte de Mesonero estoy completamente de acuerdo $^{6}$, no lo estoy tanto en lo que atañe a la falta de coherencia: sin ser una

"Los límites de Mesonero como escritor los ha definido contundentemente Alberto Gil Novales al decir que «su fama es tan grande como sus contradicciones, y en el fondo su ausencia de pensamiento» (1991, pág. 433). 
obra redonda, hay una evidente unidad proporcionada por el punto de vista, la continuidad espacial y la progresión cronológica, además de por la peripecia histórica que sirve de eje a toda la rememoración. En cualquier caso, la aceptación e influencia de las Memorias demuestran que acertaron a gustar al público y que la forma de combinar esos ingredientes dio como resultado un producto ajustado a las necesidades de los lectores y capaz por tanto no sólo de satisfacerlas, sino de modificar el curso de una parte de la literatura española en determinada dirección. Es posible, entonces, que lo que a Caballé le parecen defectos y limitaciones -y que de hecho lo son-fueran justamente la clave de su éxito. Trataré ahora de desarrollar los diferentes extremos de esta receta literaria.

La fórmula ajustada por Mesonero descansa principalmente sobre una peculiar relación entre el yo y la Historia que se diferencia de los modos de concebir y representar la identidad individual que se habían practicado en otros escritos autobiográficos. En la autobiografía entran siempre en juego en diferentes grados dos elementos esenciales: el yo y la Historia, entendiendo ésta en sentido amplio, el entorno en que se desenvuelve la vida del autor. Algunos autobiógrafos tal vez han fabulado un yo solipsista, autosuficiente, que se puede separar de su marco espacio-temporal sin perder su propia identidad y coherencia, pero eso es sólo una fantasía hija del egocentrismo y de una inútil protesta contra la realidad. La identidad de un individuo es producto de un momento y de un lugar, un clamoroso hic et nunc del que resulta imposible prescindir: no se puede aislar en ella lo que es influencia del medio, de la educación, de la coyuntura histórica y del devenir de la colectividad, para quedarte solamente con una hipotética esencia, porque después de quitar todo eso no queda nada. El yo, por tanto, es un ser histórico, cuyos valores puramente individuales están arraigados inextricablemente en valores colectivos como el espíritu de clase, la identidad de género, de nación, de raza, las creencias religiosas, políticas, sexuales...

Esos dos niveles de acercamiento a la personalidad del autor, a través del yo o a través de sus circunstancias por emplear términos orteguianos, se han barajado de formas muy diversas en la autobiografía occidental y cada discurso autobiográfico incide de manera distinta en la proporción y el enfoque que se aplica a estos ingredientes: el énfasis puesto en el yo o en el entorno es precisamente lo que define la clásica separación entre autobiografías y memorias. El memorialismo de Ramón de Mesonero Romanos lleva a su extremo la preocupación por observar el entorno en que se desarrolló la propia vida. Dicho de otra manera, en la propuesta de Mesonero la conciencia del yo es acaparada casi por entero, por no decir que reemplazada, por la conciencia histórica. Para estudiar esta cuestión, por consiguiente, es menester analizar qué tipo de historia y qué tipo de yo vemos 
en las Memorias de un setentón. A esto añadiré finalmente una tercera cuestión, esencial en el discurso memorialístico de Mesonero: el espacio geográfico, es decir, la ciudad de Madrid.

Según Anna Caballé, las transformaciones políticas, sociales y científicas que vive el siglo XIX «son motivo [...] del despliegue testimonial de cuantos asistieron más o menos activamente a tan abundantes transformaciones. [...] Se trata de un fenómeno de largo alcance, no exclusivamente español, con rasgos comunes en todo el dominio europeo y americano: rasgos apoyados en la pasión por el documentalismo y la historicidad (no en vano al siglo XIX se le ha calificado como el siglo de la Historia) que conformaron el tipo de hombre característico del siglo» (1991, pág. 143). El historicismo y la necesidad del testimonio político justifican en el XIX el enorme auge en Europa de una literatura autobiográfica volcada a esas materias. Pero hay, sobre todo, una evidente tendencia a sustentar sobre ese historicismo un fuerte sentimiento nacional. No en vano esa centuria es la que vivió, a partir de la revolución francesa y las guerras napeolónicas, el surgimiento del nacionalismo, que no dejaría de afianzarse desde entonces. La obsesión por construir un Estado fuerte y centralizado implica la necesidad de articular una identidad nacional que lo cohesione con un agresivo sentimiento individual y colectivo de pertenencia. Esto requiere elaborar una lectura de la Historia, tanto remota como reciente, que actúe como un ideal comunitario en que la gesta nacional se imponga sobre los particularismos de clase, de partido o de cualquier otro tipo. En el caso español la gesta fundacional reside en la gloriosa revuelta antifrancesa de 1808 , convenientemente transmutada de revolución española -como fue denominada por sus contemporáneos- en guerra de la independencia -según el patriótico término que se impuso a lo largo del XIX-, el único suceso histórico reciente en condiciones de suscitar una visión heroica, unificadora y coronada por el éxito.

Las Memorias de un setentón buscan justamente construir una versión de la historia española de la primera mitad del siglo, seleccionada no por la memoria subjetiva de su autor-narrador, sino asumiendo una memoria colectiva que está influida por las previas reconstrucciones historiográficas e iconográficas de ese periodo. Esa conciencia colectiva selecciona unos hechos concretos y sus interpretaciones. Si Mesonero quiere contar la experiencia española de su tiempo, y no sólo la suya propia, tiene que ajustar sus recuerdos subjetivos a esa selección, es decir, tiene que conectar con las expectativas que los lectores poseen ya sobre la época, incluso si el protagonista de las memorias no fue testigo de los acontecimientos o si éstos no influyeron para nada sobre su vida particular. En suma, la panorámica histórica de la memoria colectiva domina sobre la memoria indivi- 
dual, de tal manera que la forma de organizar la materia no es muy diferente a la de una obra de ficción que tiene toda la libertad posible para seleccionar sus contenidos, los Episodios nacionales de Galdós.

Esta recreación y estilización literaria de la historia nacional que emprende Mesonero exige un amplio distanciamiento cronológico. La lejanía entre el narrador y lo narrado es la clave para adoptar un tono, ya nostálgico, ya crítico, ya humorístico, acerca del pasado evocado. En la fórmula autobiográfica de las Memorias de un setentón una parte esencial reside en ese setentón que se reclama jactanciosamente en el mismo título; por eso una de sus influencias más permanentes sobre la literatura autobiográfica española es la epidemia de títulos que indican la ancianidad del protagonista (en esto había sido precedido por Alcalá Galiano). En este sentido, James D. Fernández (1992) señala la existencia de un paradigma de autobiografía basado en el esquema de un anciano, testigo privilegiado de la marcha de la historia: «The posture of the old man/unique witness is frequently assumed by the autobiographer/chronicler of modernity; the claim to authority» (1992, pág. 104). Esto no es algo consustancial a cualquier tipo de autobiografía: la memoria reside en la conciencia del tiempo, pero no necesariamente en la vejez; ésta en cambio sí es una condición obligada en el modelo histórico-costumbrista que propone Mesonero. Así, la sincronía que es precisa para el cuadro de costumbres ha de convertirse en diacronía si se desea introducir un enfoque nostálgico y evocador en la autobiografía, como han explicado Escobar y Álvarez Barrientos (en Mesonero 1994, págs. 50-52).

La mirada retrospectiva y la insistencia en el tiempo transcurrido entre la escritura $-\mathrm{y}$ la lectura $-\mathrm{y}$ los hechos narrados forman parte también del proceso de despolitización que Mesonero aplica a sus memorias, ya que esa distancia es la que justifica una visión depurada de la política y de la historia, con sus aristas limadas, como si la pátina de polvo dejada por el transcurso de los años hubiese hecho inútiles y sin sentido las luchas políticas, las pasiones y desvaríos partidistas y todo aquello que entonces parecía importante o terrible, y que ahora queda igualado en la memoria de un anciano? ${ }^{7}$. Porque además de ser un viejo que recuerda el pasado, el narrador autobiográfico propuesto por Mesonero se caracteriza por su condición de espectador: no ha sido protagonista de la vida pública,

${ }^{7}$ Anna Caballé, al advertir del giro temático dado en la segunda parte y el abandono casi total de la materia política tras la muerte de Fernando VII, atribuye este cambio a que «la pluma del cronista sólo se siente firme en la evocación del pasado lejano, y nada peligroso, dicho sea de paso. En cambio, decae cuando se trata de enfrentarse al presente de la escritura, que rehúye, abandonando las Memorias al llegar a 1850 (después de haber aceptado Mesonero una concejalía del Ayuntamiento de Madrid)» (1991, pág. 146). 
sino un particular. Mientras que eso hasta entonces deslegitimaba la escritura autobiográfica, para el Curioso Parlante es precisamente su fuente de legitimación, inaugurando una pléyade de particulares que se entregan a contar sus vidas y los hechos de sus tiempos sin haber figurado apenas en el escenario principal de la historia.

Hasta qué punto se distancia el autor de la política es una cuestión que hay que matizar, ya que en realidad es un elemento presente en las Memorias igual que en la propia vida del Curioso Parlante. ${ }^{8}$ Desde luego, su visión no deja de estar fuertemente sesgada en un determinado sentido: refleja los valores de la clase media liberal conservadora de comienzos de la Restauración, que acusa las conmociones revolucionarias del Sexenio y la prolongada división social abierta en 1808. La despolitización que opera Mesonero Romanos en su evocación histórica consiste en primer lugar en no presentarse a sí mismo como político-incluso ocultando a los lectores las tareas públicas en que tomó parte-, sino como un portavoz de la gente común, de la sociedad, un concepto que en su consideración queda reducido a las clases medias?. No pretende, por tanto, relatar ni defender una actuación política ni una posición de partido. Como indica en la introducción, su condición de persona independiente le reduce «a considerar los sucesos políticos únicamente bajo su aspecto exterior, digámoslo así, fijando particularmente su atención en los que corresponden a la vida literaria y a la cultura social, a que dedicó su especial estudio» (Mesonero 1994, págs. 88-89). El madrileño está distanciándose de forma calculada del modelo de memorias políticas que se había ya institucionalizado en la literatura española y frente al cual formula el suyo propio, que se legitima precisamente por no ser una crónica política, sino centrada en la vida social y cultural, en la pequeña historia, aunque inevitablemente tenga también que ocuparse de la grande. Anna Caballé (1995, pág. 153) recuerda que, si en la primera mitad del XIX el autobiógrafo se sometía al discurso político, el estilo que impone Mesonero transfiere esa servidumbre al discurso histórico: «el

${ }^{8}$ «...como habrá constatado cualquiera que se haya acercado a sus Memorias y al resto de su obra, Mesonero constantemente lanza juicios y opiniones políticas -incluso con sus silencios-, convirtiéndose en un personaje inmiscuido en asuntos políticos, es decir, activo y decisivo en mucho de lo que sucede a su ałrededor: el hecho más palpable es su actividad en la política urbanística de la ciudad de Madrid, en la mejora del nivel cultural de la corte y de las instituciones que en ella residen...» (Álvarez Barrientos 1995, pág. 43).

"En la introducción declara Mesonero que su deseo es hacer al lector «apreciar las circunstancias de carácter y condición de las clases medias acomodadas e independientes de aquella época» (1994, pág. 89). Hay un largo pasaje mucho más contundente sobre el papel político que atribuye a las clases medias y a las bajas en la vida nacional, con evidente ventaja para las primeras (Mesonero 1994, págs. 269-270). 
proyecto autobiográfico se confunde con el historiográfico, y buen ejemplo de esa fusión/confusión la tenemos en las Memorias de un setentón, de Mesonero Romanos» (Caballé 1991, pág. 146).

Pero en ese historicismo hay al menos dos planos de contenido. Mesonero declara que va a centrarse «en aquellos pormenores y detalles que por su escasa importancia relativa o por su conexión con la vida íntima y privada, no caben en el cuadro general de la historia, pero que suelen ser, sin embargo, no poco conducentes para imprimirla carácter y darla colorido» (Mesonero 1994, págs. 87-88). Es decir, por un lado está el curso general de la historia de la nación, los acontecimientos políticos y militares; por otro, la vida privada de los ciudadanos, la manera en que éstos vivieron aquellos sucesos, las costumbres, las anécdotas, la marcha cultural y literaria y todo lo que configura la pequeña historia cotidiana. Lo cierto es que, en las Memorias de un setentón, aparecen los dos planos, y no sólo el segundo de ellos como quiere hacernos creer su autor. Ya al desarrollar sus ideas sobre la novela, «Mesonero prefiere la novela de costumbres entreverada de la histórica, e incluso, de la Historia a secas. Es entonces cuando, a su parecer, alcanza el valor máximo» (Álvarez Barrientos 1995, pág. 33). Al pasarse al memorialismo, mantendrá vivo este principio, combinando lo histórico y lo costumbrista; en el futuro, como se verá, sus imitadores optarán por mantener esa mezcla o se decantarán, en el caso más frecuente, por el costumbrismo.

Esta mezcla de dos clases de asuntos está directamente relacionada con la despolitización. En efecto, el narrador muestra su continuo desprecio de los partidismos, en realidad su desprecio de la propia política, entendida como fuente de disolución de la concordia nacional, un ideal mesocrático que a la hora de la verdad se reduce a un firme deseo de que se mantenga el orden, se respete la propiedad y no se produzcan rupturas traumáticas con el pasado. Mesonero expresa su lealtad a un ideal de progreso y de reforma desde el que formula valoraciones siempre negativas a un lado y a otro del arco político. El tiempo transcurrido le permite adoptar esa pose de apoliticismo aparente para centrarse en lo que realmente le interesa: extraer del curso histórico un fantasmagórico espíritu nacional que resulta, por arte de birlibirloque, diferente de los intereses y las ideas encarnadas por unos y por otros sectores sociales y políticos. Así, la historia resulta de verdad nacional y patriótica, porque se ha separado artificialmente de las fuerzas que, de hecho, la impulsaron ${ }^{10}$. Las Memorias de un setentón dejaron ese legado

\footnotetext{
"Esta posición aparece con meridiana claridad al hablar de los agitados primeros meses de 1814, antes de la vuelta de Fernando VII al trono de sus antepasados: «En medio, empero, de esta agitación febril, de esta lucha encarnizada de las banderías políticas, el solo recuerdo de una fecha vino a calmar las enconadas pasiones, vino a establecer una tregua, siquiera breve, en las intrigas políticas;
} 
de apoliticismo nacionalista a muchas de las obras autobiográficas que recibieron su influencia, y que incluso extremaron la visión costumbrista y nacional (a menudo ya sólo local) frente a la historia y la política.

Pero ése es sólo un problema: delimitar el papel de la política y la Historia respecto a la vida social y al anecdotario costumbrista. Hay un segundo problema, que le 'resulta más amenazador: delimitar el territorio de la rememoración de su vida personal y el de la vida pública, colectiva. Son frases muchas veces citadas, pero es inevitable reproducirlas aquí: «el escollo verdaderamente formidable [...] es la necesidad imprescindible, fatal, en que se encuentra de hablar en nombre propio, de usar el satánico yo [...] y haber de combinar en cierto modo los sucesos extraños que relata con su propia modestísima biografía» (Mesonero 1994, pág. 89). Así pues, quedan establecidos tres planos en el contenido: la biografía personal del autor, la pequeña historia social y la gran historia general (y política) de la nación ${ }^{11}$. En principio, el propósito declarado de Mesonero es ocuparse sólo del segundo, e incidentalmente de los otros dos, pero lo cierto es que el problema persiste de manera insistente durante todo el transcurso de las Memorias obligando a un incómodo narrador a hacer excepciones al proyecto inicial, volver a él, desviarse de nuevo, etc., en una larga serie de transiciones entre

\begin{abstract}
y esta fecha providencial, que acertaba a reunir a todos en un solo pensamiento espontáneo, nacional, sublime, era la por siempre memorable del DOS DE MAYO» (pág. 205). «Imposible sería pintar aquí con sus vivísimos colores el entusiasmo patriótico [de la primera celebración del Dos de Mayo], la unción religiosa con que el pueblo entero de Madrid asistió [...]. Muchas y ostentosas solemnidades, más o menos oficiales, ha presenciado después este pueblo, sin tomar parte activa en ellas [...]; muchas ovaciones entusiastas ha prodigado una parte de la población, mientras que acaso la otra yacía encerrada, proscrita, o huyendo de la arrogante triunfadora [...]. Pero el Dos de Mayo de 1814 todos los habitantes de Madrid, sin excepción alguna, se sentían animados de un mismo sentimiento, de una misma, aunque dolorosa, satisfacción; y hasta las diversas banderías de liberales y serviles venían a confundir su pensamiento ante una misma idea; venían a renđir su tributo ante un mismo altar» (pág. 209). Eso no quiere decir que Mesonero no tome partido: aunque distribuye sus censuras en todas las direcciones, deja claras sus simpatías por la causa constitucional, por su sentido modernizador, burgués y progresista, mientras que condena a los serviles. Así, la reacción de 1814 le parece el origen de los males españoles: «Ingratitud y torpeza política que no tiene semejante en la historia moderna, y que fueron, a no dudarlos, las generadoras de tantos levantamientos insensatos, de tantas reacciones horribles como ensangrentaron las páginas de aquel reinado, y lo que es más sensible aún, que infiltrando en la sangre de una y otra generación sucesivas un espíritu levantisco de discordia, de intolerancia y encono, nos ha ofrecido desde entonces por resultado tres guerras civiles, media docena de Constituciones y un sinnúmero de pronunciamientos y de trastornos que nos hacen aparecer ante los ojos de Europa como un pueblo ingobernable, como una raza turbulenta, condenada a perpetua lucha e insensata y febril agitación» (pág. 213).
\end{abstract}

1 Escobar resume esta idea diciendo que Mesonero pone en práctica «un plan [...] histórico-costumbrista con dimensión autobiográfica» (1993, pág. 279) y que «el texto [...] se constituye en la intersección textual de tres modelos narrativos: la autobiografía, las memorias y el artículo de costumbres» (1993, pág. 286). 
un plano y otro que suponen un buen ejemplo de ese «metadiscurso inquieto» con que Lázaro Carreter (1983, pág. 22) define el estilo autobiográfico de Santa Teresa, pero que es muy común en el género de la autobiografía ${ }^{12}$. Todas esas rectificaciones, a veces contradictorias, muestran el punto débil que posee el proyecto de las Memorias de un setentón, la fragilidad de un ejercicio de la memoria que en realidad tiene mucho de reconstrucción libresca y de estilización literaria, fuerzas más poderosas que el propio recuerdo subjetivo, ya que si tuviera que limitarse a éste el relato estaría cuajado de lagunas y perdería gran parte de su interés. Veamos algunos ejemplos espigados de los primeros capítulos:

[...] al trazar el anciano la reseña de suceso tan remoto [el motín de Aranjuez], dispensaráse al niño de entonces se reduzca a presentarla en los términos sencillos, infantiles, casi risueños con que quedó grabada indeleblemente en mi memoria (pág. 92).

$Y$ en tanto que el niño duerme el sueño de la inocencia, aprovecha el hombre su silencio para trazar en algún modo el episodio local de aquel célebre motín, con todos los pormenores de la mise en scène por primera vez empleados en este siglo, en nuestro teatro madrileño (pág. 96).

[...] como vuelvo a repetir que ni mi propósito ni la tierna edad en que me encontraba sean conducentes a escribir historia [...] sólo habré de limitarme a trazar impresiones propias [del periodo previo al Dos de Mayo], a narrar algunos incidentes de los que pude presenciar o estaban al alcance de mi limitadísima comprensión. Fácil me sería, consultando libros y periódicos, reproducir bien o mal una de tantas relaciones de aquellos trascendentales sucesos; pero esto, lejos de acrecer, entiendo que debilitaría el interés de este relato, que si alguno tiene, no puede ser otro más que la forma sencilla, veraz, íntima e infantil con que brota espontáneamente de mi pluma (pág. 109).

Esta humillante puja de mísera adulación y de artera falsía [de la corte de Fernando VII ante Murat], consignada está en la historia, y sería inoportuno reproducirla aquí [sin embargo lo hace], tanto más cuanto que sólo por ecos vagos podía llegar hasta mi tierna comprensión (pág. 111).

Por mi parte, pobre criatura de cinco años escasos [...] sólo habré de limitarme a consignar la fiel pintura del interior de mi casa y familia en tan tremendas horas [del Dos de Mayo], lo que, a falta de importancia general, habrá de ofrecer al menos algún interés relativo por su veracidad y su colorido (pág.

${ }_{12}$ Ya algún crítico ha advertido esta peculiaridad: «Throughout the Memorias, Mesonero Romanos promises time and time again not to invade the limits of history, though he never quite manages to keep his promise. [...] each incursion into history or politics is introduced by a distancing expression» (Fernández 1992, págs. 108-109). 
116). [Pero, en cambio, para contar los días y semanas subsiguientes modifica su criterio:] alternaron vicisitudes tales, que sería imposible de todo punto prescindir de ellas, si ha de darse el enlace debido a esta sencilla narración, por mucho que pretenda reducirla a los términos que me propuse (pág. 125).

Los trascendentales acontecimientos acaecidos durante la segunda mitad del año 1808, y la vertiginosa rapidez con que se sucedieron, me obligaron a mi pesar, en el capítulo anterior, a extralimitarme de mi propósito, penetrando algún tanto en el dominio de la Historia, siquiera no fuese más que para señalar la marcha de los asuntos exteriores con relación al cuadro íntimo que me propuse trazar en el presente relato (pág. 147).

Cansado de ir, como quien dice, a la zaga de la Historia en los capítulos anteriores, porque así lo requería la magnitud de los acontecimientos durante los seis años de la Guerra de la Independencia, permitido me sea [...] reposar algún tanto de aquella narración histórico-anecdótica, para trazar en la presente un episodio que, aunque puramente personal y de índole doméstica o privada, tiene relación con aquella época. [...] Con esto aprovecho la ocasión de volver por el momento a mi propósito primitivo, que no fue ni pudo ser otro que el de reflejar en estos apuntes el colorido característico de aquella sociedad, su manera de ser, como ahora se dice, sus costumbres, sus deseos y modestas satisfacciones (pág. 185).

Por muy opuesto que sea a mi carácter y al tenaz propósito con que he sabido conservar a mi modesta pluma en el más absoluto apartamiento de la política, no es posible en ocasiones como la presente [la reacción absolutista de mayo de 1814] prescindir de tomar en cuenta aquellos hechos históricos, que tanta influencia tuvieron en la marcha, ya progresiva o ya retrógrada, de la civilización y de la cultura, que es lo que bien o mal me propuse reflejar en estas Memorias, ayudado únicamente de mi buena fe, de mi independencia de los partidos y de la más absoluta veracidad (pág. 215).

[...] a falta de criterio propio [sobre el carácter de Fernando VII], que por mi tierna edad no podía formar, habréme de limitar a reproducir las apreciaciones y los comentarios que de unos y otros escuchaba sobre dicho carácter (pág. 249).

[Tras contar la muerte de su padre en enero de 1820.] Todo esto, que a mí solo interesa, hubiéralo omitido, a no ser porque en esta reseña de mis reminiscencias personales, que me propuse hacer en la presente obra, enlazándola con los acontecimientos públicos, no creo inoportuno hacer mención de la notable coincidencia que ofrecía mi entrada en la vida con la inauguración de una época nueva en la marcha histórica de nuestra sociedad (pág. 265). 
Es decir, pese a haber declarado sus intenciones de limitarse a evocar la vida social y literaria, así como los pormenores de la historia que sólo la memoria de un testigo directo puede retener, su escritura se debate entre continuas vacilaciones: el miedo a hablar demasiado de sí mismo, el peligro de que ceñirse a su experiencia directa dé lugar a un cuadro incompleto y deslavazado -es decir, que no satisfaría las expectativas del lector- y le impida dar una visión completa -su visión- del curso general del país, pero también el peligro de que prescindir de su experiencia directa sustraiga lo más original de su propuesta literaria, que es el componente autobiográfico, el entrelazamiento de su propia vida con la aventura española de la primera mitad del XIX. Mesonero se mueve en un terreno inseguro que a poco que se descuide le aparta del equilibrio que persigue.

Pero, en cualquier caso, su fórmula literaria es autobiográfica, se construye bajo la presencia de un yo ineludible -sea satánico o angelical-, lo que implica que otro problema que debe solventar el escritor es el de delimitar qué cosas de sí mismo y de su memoria subjetiva está dispuesto a ofrecernos. Su opción no deja lugar a dudas y viene determinada por el prioritario interés mostrado hacia el entorno sociohistórico: opta por la máxima neutralidad y ocultamiento. Tras enriquecer su receta con tanto de historia, costumbrismo, anecdotario, etc., no es extraño que el otro ingrediente resulte escaso, poco sabroso y, para muchos, decepcionante, especialmente si se trata justo de aquel material que se supone más característico del género autobiográfico. Lo ocurrido lo resume bien el siguiente comentario: «Hemos visto que al costumbrismo le es esencial la perspectiva autobiográfica del narrador-testigo, del observador concreto y personificable. Sin embargo, cuando este yo intenta presentarse a sí mismo, acaba viéndose no como un individuo, sino como un tipo más de los que componen el cuadro social. En el autorretrato domina lo típico sobre lo individual, lo externo sobre lo interno y, en último término, la personalidad misma sólo resulta descriptible tomando la historia general como paradigma» (Sánchez Blanco 1983, pág. 43) ${ }^{13}$.

13 Anna Caballé lo ha expresado de forma más dura: «El hecho de que las Memorias de un setentón se inicien en marzo de 1808 [...] ya es revelador del propósito fundamental, consciente o inconsciente, de quien las escribe: hacer discurrir su vida con la historia de los abundantes sucesos notables de que Mesonero Romanos fue testigo, y con el estado de la opinión pública en materia política y social. El resultado es que el sometimiento del escritor al discurso histórico es absoluto, y ello va, naturalmente, en detrimento de las Memorias como género (relativamente) autónomo desde un punto de vista literario; pues su objeto viene a coincidir con el objeto de la historia, o sea, dar cuenta de los hechos que han tenido trascendencia. Hechos que son narrados por el memorialista desde una perspectiva personal, de mayor colorido y vivacidad que el frío y desangelado relato histórico, pero ajenos al esfuerzo de un hombre por erigir su personalidad. Por otra parte, Mesonero no comprende que la presión de la historia exige el subjetivismo fluctuante de quien a ella se ha visto sometido de algún modo» (1991, pág. 146). 
Esto, en realidad, es un rasgo común de la autobiografía española en casi toda su historia, y desde luego en el siglo XIX: si Mesonero tuvo tanto éxito es precisamente porque conectó con éste como con otros aspectos del gusto literario español ${ }^{14}$. Caballé ha desarrollado mucho en sus estudios la cuestión del ocultamiento de lo íntimo en la literatura autobiográfica española. Pese a la gran eclosión autobiográfica española en el XIX -dice-, estas obras no conceden libre espacio a la expresión de la propia individualidad. «Será que apretaban demasiado las cuestiones públicas para que estos memorialistas cedieran a la presión de lo personal» (Caballé 1991, pág. 144). Además, estaba vigente la idea de que estas obras debían ofrecer un ejemplo de virtudes, ser modelo de otras vidas, «y así, lo más íntimo, lo más espontáneo, las anécdotas picantes o los hechos contradictorios debían suprimirse, seleccionándose para el público cuanto en una vida pudiera calificarse de grande y digno y se manifestara en consonancia con el mundo de los valores y los convencionalismos sociales» (Caballé 1991, pág. 144). Se trata de textos en que el narrador busca en sí mismo el recuerdo de hechos externos: «...el tipo básico de recuerdos que constituyen el material autobiográfico decimonónico es el de los recuerdos trascendentes, aquellos cuyo objeto es exterior a la consciencia que los recuerda...» (Caballé 1991, pág. 145).

En este tipo de memorias decimonónicas: «...el autor es testigo, pero al servicio de la fama de otros, desapareciendo casi en la narración de los acontecimientos, a excepción de algunas anotaciones sobre los sentimientos particulares que motivaron sus propias acciones, marginales respecto a la acción principal, por lo que apenas se puede hablar de auténticas autobiografías» (Sánchez Blanco 1983, pág. 41). Ésta sería la explicación a la mezcla de vida personal e historia general en detrimento de la primera en la mayoría de los autores españoles. El rechazo del modelo de individualidad romántico es en España profundo, y no sólo en los sectores más conservadores ${ }^{15}$. Los modelos perfectos de esa identificación

\footnotetext{
${ }^{14}$ Sobre la pudibundez de los autobiógrafos españoles hay numerosos testimonios de los propios autores y de la crítica, que en un futuro tendrían que ser matizados en su pretendido valor general por un mejor conocimiento de los textos, pero para el contexto que explica las Memorias de un setentón son válidos. Un ejemplo creo que no muy conocido, que viene de una modalidad autobiográfica mucho más egocéntrica que la de Mesonero, lo ofrece Pérez Escrich en El frac azul, donde advierte en el prólogo que «Madrid no es París, donde los escritores son bastante despreocupados para escribir sus memorias; donde Chateaubriand dice que ha tenido hambre delante del escaparate de una fonda; Rousseau que ha robado y conducido por él mismo tres hijos a la Inclusa [...]. Allá, es decir en Francia, los escritores, sin encomendarse a Dios ni al diablo, cuando escriben algo de sus vidas privadas, sacan a relucir los nombres propios de sus amigos, sin tomarse la molestia de pedirles permiso [...]. Pero nosotros los españoles somos más graves, más circunspectos, más quisquillosos, sin duda porque aún nos queda algo de los caballeros de la Edad Media» (1864, págs. 6-7).

${ }_{15}$ «Aunque la evolución hacia un análisis más detallado de las vivencias subjetivas y de los rasgos individuales no se puede negar, también es verdad que este camino se recorre en España con bas-
} 
de la propia vida con la historia estarían en Alcalá Galiano -del que Sánchez Blanco dice que «su descripción no está excesivamente individualizada y podría cuadrar a la de cualquier miembro de la primera generación de liberales» (1987, pág. 638)- y Mesonero Romanos, quien avanza un paso descubriendo el ámbito de lo privado (no de lo íntimo y personal, sino de la pequeña vida burguesa y no sólo la gran vida política).

Por fin, el último gran elemento constitutivo de la propuesta que ofrece Mesonero en sus Memorias es la vinculación de la memoria a un espacio geográfico concreto, presente en el relato como protagonista, no sólo como escenario. En su caso se trata de Madrid. Cualquier lector puede apreciar el meticuloso pormenor con que el memorialista especifica los nombres de las calles, las direcciones y detalles de los domicilios donde viven los personajes, los cambios urbanísticos operados desde entonces, el aspecto general de la ciudad y el particular de infinidad de lugares concretos ${ }^{16}$. En principio, este arraigo parece que está destinado a limitar la comprensión de la obra a un público local, único que está en condiciones de valorar en su justa medida el espacio geográfico mostrado. Sin embargo, el madrileñismo no convierte las Memorias de un setentón en una obra localista, como prueba su amplia y dilatada recepción por el público español. Esto es así, a mi juicio, por dos razones que en realidad vienen a ser una sola: por el extenso componente histórico, que trasciende el marco local en favor de una identificación colectiva, y por una visión centralista de la vida nacional que convierte a Madrid en un patrimonio común de la memoria española, sobre todo en función de ser el escenario privilegiado de la historia nacional.

El nacionalismo decimonónico también implica, además de una lectura de la historia cohesionadora del orgullo patriótico, una jerarquización del territorio según las prioridades del Estado centralizado burgués. La conciencia histórica colectiva a la que antes me he referido no implica sólo la interiorización de los procesos políticos, sociales y militares que ha vivido una sociedad, sino que también interioriza un espacio concreto, un territorio, incluso unas calles y edificios: es una conciencia local tanto como temporal, según la cual la pertenencia a un

tante independencia de los otros ámbitos culturales europeos. El desarrollo de una nueva sensibilidad, y de una reflexión sobre ella, corre paralela a la difusión de las ideas políticas liberales y del gusto romántico pero, paradójicamente, el modelo de individualidad que se adopta para la autobiografía no corresponde al del sujeto lírico del romanticismo» (Sánchez Blanco 1987, pág. 636).

${ }^{16}$ Ésta es otra técnica aprendida del cuadro de costumbres, como estudian Escobar y Álvarez Barrientos: «La incidencia [...] sobre lo circunstancial, sobre el aquí y ahora espacio-temporal, dotaba al cuadro de costumbres de una capacidad comunicativa muy señalada, pues provocaba sobre el lector un efecto de verosimilitud, de cosa real cercana a él y conocida que se venía pidiendo a la literatura desde el siglo XVIII» (en Mesonero 1994, pág. 25). 
ámbito geográfico define la propia personalidad en la misma medida que los acontecimientos vividos. Por ello no resulta extraño el protagonismo adquirido por Madrid en las Memorias de un setentón, ya que los acontecimientos históricos se describen y analizan con óptica centralista: «Madrid es el epicentro de casi todos los relatos autobiográficos, la mayoría de ellos a medio camino entre la literatura de costumbres inspirada en la realidad ambiental y un sentimiento indudable de autosatisfacción, que conduce, por ejemplo, a enfatizar los hechos de la Independencia o el espíritu liberal gaditano» (Caballé 1991, pág. 143). Es, por tanto, lógico que en su carta a Patricio de la Escosura, de la que luego hablaré, al comparar las ventajas de su propio proyecto memorialístico frente al que aquél había dado a luz, indique Mesonero que en contraste con la asendereada y movida trayectoria política de Escosura, su mérito es ser espectador y no protagonista de la vida pública, y también «mi constante permanencia en mi pueblo natal, teatro principal de nuestra historia política y literaria» (en Núñez de Arenas 1947, pág. 398). El madrileñismo aparece así como una condición para quien ansíe convertirse en cronista de la vida nacional ${ }^{17}$.

Mesonero es, por tanto, el primer autobiógrafo que tematiza como una parte esencial de su relato una ciudad, un territorio; en eso ha de considerársele un precursor de los autores que le seguirán por todo el país: las evocaciones de un Madrid en que se pretendía resumir y simbolizar a toda España, darán lugar posteriormente a una cascada de imitaciones de ese modelo «en provincias», como dirían los capitalinos, pero sólo la Villa podía aspirar a condensar en sus calles el devenir histórico de toda la nación.

Resumiendo lo dicho hasta aquí, la propuesta autobiográfica de Ramón de Mesonero Romanos implica los siguientes elementos, mantenidos en el conveniente equilibrio que no todos sus imitadores sabrán darles: el objeto de interés

17 «Mesonero Romanos has frequently been called el autor de Madrid (the author from/of Madrid), in reference to the fact that he was an early cultivator, if not an inventor, of madrileñismo. We might take this expresion in a different way though, and propose that Mesonero Romanos not only writes of, and from Madrid, but also writes Madrid, he is its author. He does this in at least two different ways. First, in his autobiography, he makes Madrid the protagonist of a text [...]. Second, as an urban planner, we see Mesonero Romanos throughout his Memorias proposing improvements, demolitions, and changes of names...» (Fernández 1992, págs. 106-107). Según este crítico, no se trata de algo inocente: Mesonero busca una identificación entre la nación española, Madrid y la clase media, fabricando así una conciencia nacional. Por eso, una de sus estrategias autobiográficas consiste en ligar su historia personal con Madrid y con España entera: «Madrid eventually becomes the protagonist of the Memorias; Mesonero Romanos sees fit to replace the words I witnessed with the words Madrid witnessed. The autobiographer becomes the eyes and the voice of the city; moreover, the city becomes a person. Indeed, Madrid shares many characteristics with the protagonist of a novel, or perhaps better yet, of an epic» (Fernández 1992, pág. 108). 
preferente es evocar el pasado a la busca de un ideal colectivo de identidad nacional; el sujeto de la obra no es tanto el autor como «los españoles», que encarnan una selección de los contenidos en función de su memoria colectiva; hay un distanciamiento cronológico entre el narrador (un viejo) y lo relatado; ese narrador es un particular, testigo privilegiado y no protagonista de la historia; se presume de despolitizar el texto en favor de un vago deseo de mostrar el fondo del espíritu nacional más allá de las despreciables luchas partidistas; la materia abarca la historia político-militar, pero sobre todo la vida cotidiana, cultura, costumbres, anécdotas y vivencias de la comunidad; el yo del narrador adopta una actitud neutra y tiende a ocultar su intimidad bajo su pose de portavoz; y, finalmente, el espacio geográfico ocupa un destacado papel en la construcción de esa memoria. La influencia, y también los orígenes, de las Memorias de un setentón en la autobiografía española tendrán por consiguiente que ceñirse a esta caracterización, en todo o en parte, como seguidamente paso a analizar.

\section{LOS PRECURSORES: MOR DE FUENTES, ALCALÁ GALIANO Y ESCOSURA}

Este formato autobiográfico que Mesonero populariza no es, desde luego, creación exclusivamente suya ni surge de la nada. Sus inmediatos contemporáneos, principalmente Alcalá Galiano y Escosura, tienen mucho que ver con el hallazgo del madrileño, pero también ellos continúan una línea que venía decantándose desde antes ${ }^{18}$. El antecedente más claro es, a mi criterio, José Mor de Fuentes (1762-1848) con su Bosquejillo de la vida y escritos delineado por él mismo (1836). Este escritor aragonés es el último miembro de la generación ilustrada que acomete la tarea de escribir una autobiografía personal, que no consista sólo en una vida literaria detallando sus escritos y tareas intelectuales ni en unas memorias políticas o justificativas. Es también el único que concluye su obra y la da a la imprenta's. Frente a otros autores de su generación, Mor de Fuentes da un

${ }^{18} \mathrm{Mi}$ deseo de restringirme al ámbito autobiográfico hace que no insista en el papel clave jugado por los Episodios nacionales de Galdós, pero se trata de una influencia que no puedo dejar de mencionar. Las dos primeras series de Episodios se escalonaron entre 1873 y 1879; se sabe por una carta al novelista canario de 23-V-1875 que éstos fueron muy bien acogidos por Mesonero, quien se declara como una de las fuentes orales del joven Galdós, cuyo ejemplo le animó en cierta medida a poner sus recuerdos por escrito. Así superaba el estancamiento creativo en que llevaba muchos años sumido, después de haberse agotado su fórmula de cuadro de costumbres. Cf. Escobar y Álvarez Barrientos (en Mesonero 1994, págs. 54-58).

${ }^{19}$ Los otros dos casos contemporáneos serían Francisco de Saavedra (1746-1819), que escribió, pero no concluyó, una espléndida autobiografía en los primeros años del XIX bajo el título de 
paso más cuando en Barcelona el año 1836, siendo ya un anciano, se decide a entregar a las prensas de su editor y protector, Antonio Bergnes de las Casas, una autobiografía, de hecho la primera que se imprime en España desde los lejanos tiempos de Torres Villarroel y sus imitadores Gómez Arias y Joaquín de la Ripa (obras publicadas entre 1743 y 1745) ${ }^{20}$.

Independientemente de los méritos o defectos de su trabajo, Mor se adelantó a su tiempo, y buena prueba de ello es que su obrita pasó sin pena ni gloria, no valió para sacarle del olvido literario y de la penuria económica en la que vivía, ni tampoco suscitó el interés de nadie; no hubo reediciones hasta bien entrado el siglo XX. Una de las razones de su poco éxito reside, a mi juicio, en que estaba anticipando en muchos años un tipo de evocación autobiográfica que no alcanzaría el gusto literario general hasta los tiempos en que escribieron las suyas Alcalá Galiano, Escosura y Mesonero, ya que entre éstos y el Bosquejillo no se publicó nada semejante en el país ${ }^{21}$. Aunque Mor de Fuentes sigue moviéndose en parámetros propios de la identidad del hombre ilustrado, su escrito ofrece varios elementos de lo que va a ser el modelo memorialístico de Mesonero. El punto de vista del narrador es el de un anciano escritor y patriota que recuerda un tiempo ya lejano para presentárselo a unos lectores que no lo conocieron. Como buen

Mis decenios, sin pretensión de hacerla publicar; y el cura gallego Juan Antonio Posse (n. 1766), que preparó hacia 1834 una Historia biográfica con la idea no cumplida de publicarla como justificación política, aunque en realidad era mucho más que eso e incluía, por ejemplo, un emotivo relato de su infancia. Discuto las particularidades de estos textos, del de Mor y de otros relacionados en la segunda parte de mi tesis doctoral La autobiografia moderna en España: nacimiento y evolución (siglo XVIII y principios del XIX), leída en la Universidad de Cádiz en junio de 2001, bajo la dirección de Alberto González Troyano.

${ }^{20}$ Entre la Vida de Ripa de 1745 y el Bosquejillo de Mor en 1836 no se publica ningunáa autobiografía que no pertenezca al grupo de las memorias justificativas o al de las pequeñas o grandes vidas literarias, en su sentido más restrictivo (Capmany, Llorente, Sempere, Villanueva, Rojas Clemente). Eso, en un terreno como el de la autobiografía española, de tan escasa y discontinua tradición editorial, es un hecho nuevo y relevante de sociología literaria, que apunta hacia un cambio en la estimación pública del género. De hacer caso al restrictivo criterio de Philippe Lejeune (1971, pág. 43 y ss.), que estima que sin comunicación real con el público no existe verdadero pacto autobiográfico y que no acepta obras anteriores al último tercio del XVIII o memorias políticas como autobiografías legítimas, tendríamos que afirmar que el Bosquejillo es la primera autobiografía de la literatura española. Sin ser partidario de tan rígidos límites, no dejaré sin embargo de destacar el hito que supone esta publicación.

${ }^{2 !}$ No estoy postulando una influencia directa de Mor en las Memorias de un setentón, de la que no hay prueba alguna. Sería interesante saber si Mesonero leyó el Bosquejillo, pero aunque tuvo oportunidad de haberlo leído, es más probable que no lo hiciera, puesto que el nombre del aragonés hacía años que había dejado de sonar en el mundillo literario madrileño, donde Mesonero había comenzado ya su carrera literaria, y su actividad se circunscribía por entonces a Barcelona, donde era despreciado como una antigualla por los jóvenes románticos ( $c f$. Cáseda 1994). 
ilustrado, la mirada de Mor es más crítica y más agria que la que propondrá Mesonero, pero ya se puede detectar la «complaciente tonalidad descriptiva y [...] benigna crítica social» que le atribuyen Escobar y Álvarez Barrientos (en Mesonero 1994, págs. 22-23). También trata, por otra parte, de evocar el pasado según unos criterios que no reflejan sólo la memoria individual del autor y su experiencia concreta, sino también el tipo de memoria colectiva de que hablé en el apartado anterior.

Mor de Fuentes incluye en el Bosquejillo, además de una reconstrucción del mundillo literario madrileño previo a 1808 , bastantes y muy circunstanciadas páginas sobre la Guerra de la Independencia, en concreto sobre dos momentos clave del imaginario patriótico de dicha contienda, el Dos de Mayo y el primer sitio de Zaragoza. En ellas su protagonismo personal en los hechos -inexistente en realidad, por más esfuerzos que hace el autor para disimularlo- está sofocado bajo el peso de la gesta nacional de que fue testigo. Son auténticos episodios nacionales: la memoria colectiva es la que jerarquiza, interpreta y mitifica esos asuntos en detrimento de otros, convirtiéndose en un principio de selección de la materia tan importante o más que la memoria subjetiva del individuo que cuenta su vida. Así pues, aunque el relato sigue la perspectiva personal de Mor, la dirección de la mirada se orienta según una conciencia histórica que va más allá de su experiencia personal: al contrario que los memorialistas político-militares, entremezcla su peripecia particular con los hechos más célebres de la historia nacional, intentando hacer una crónica de su tiempo que satisfaga las expectativas de sus lectores.

Otra de las características que aproximan este tipo de evocación a la que vemos en las Memorias de un setentón es que se incorporan en el relato las otras crónicas literarias o históricas que se han dedicado a los hechos. Igual que Mesonero recurre con abundancia a la obra histórica del Conde de Toreno para escribir sus Memorias -Escobar y Álvarez Barrientos ilustran en sus notas este punto de manera muy reveladora-, Mor se asombra de que Martínez de la Rosa afirme que los franceses dieron seis asaltos a Zaragoza, cuando ésa fue, según él, la media diaria de los dos meses del sitio. Asimismo, defiende a los paisanos de otras acusaciones: «Cierto papel y obra ha salido últimamente a luz, titulándose Historia de los sitios de Zaragoza, cuyo resultado primoroso es nublar las glorias, aventar el prestigio que tan excelsas hazañas dilataron por el orbe; pero el heroísmo de mis zaragozanos, a pesar de los escritores que por malicia o por torpeza vinieron al parecer a marchitarla, descollará con nuevos auges de esplendor y de patriotismo hasta la consumación de los siglos» (Mor de Fuentes 1957, pág. 389). 
No obstante, el Bosquejillo de Mor de Fuentes se separa de las Memorias de un setentón en que, a fin de cuentas, el elemento dominante es su propia autobiografía y no el testimonio documental sobre su época en que ocasionalmente deriva la narración. Con todos los matices expresados, el aspecto de crónica histórico-anecdótica es sólo uno de los elementos de la composición, no la base de la misma ${ }^{22}$.

Después de Mor, el siguiente autor de un texto autobiográfico que avanza en la misma línea que conducirá a Mesonero es el político gaditano Antonio Alcalá Galiano (1789-1865), cuya persona y obra sí podemos asegurar que fue bien conocida del costumbrista madrileño. Alcalá Galiano muestra desde el principio de su carrera gran interés por la escritura personal, ofreciendo el raro caso de haber dejado varias obras distintas en diferentes modalidades ( $c f$. Durán López 1997, n1 11): sus Apuntes para servir a la historia del alzamiento... de 1820... (1821) son las típicas memorias localizadas en un suceso concreto en el que se ha tenido parte como testigo y protagonista, a un tiempo constancia de su presencia y justificación de sus hechos. Los Apuntes para la biografia... (1865, escritos en 1850) son una escueta relación autobiográfica de sus datos personales y sus obras. En sus Memorias (1886, pero escritas entre 1847-1849) vemos la clásica recopilación sistemática y minuciosa, con documentos y datos, de un estadista decimonónico, unas completas memorias políticas y personales. Pero cuando aún no había publicado esas amplias Memorias, Alcalá Galiano revisó ese material inédito dándole nueva forma y espíritu en una serie de artículos publicados en $L a$ América entre 1862-1864: así surgieron los Recuerdos de un anciano, evocaciones sobre ambientes, infancia, sucesos del pasado, con tono nostálgico y estructura episódica y acronológica, que cubren el periodo 1800-1823. Como Mesonero, Alcalá Galiano introduce en el propio título la idea de vejez, que da la pauta de la perspectiva escogida para la rememoración. Esta obra supone un hito en la historia de la autobiografía española, por la importancia del autor, la calidad

${ }^{22}$ La proximidad entre el Bosquejillo y el memorialismo de Mesonero ha sido sugerida por Jesús Cáseda, quien, sin embargo, no desarrolla su intuición: «Entre los escritores contemporáneos de Mor de Fuentes [en realidad pertenecen a una generación claramente posterior] destacan dos, Mesonero Romanos y Alcalá Galiano, que supieron, al igual que el aragonés, desarrollar ese género a caballo entre la autobiografía y el documento inestimable de todo punto para los críticos que luego han querido estudiar la vida intelectual, política, social y literaria que ellos describieron en sus trabajos. El Bosquejillo de Mor de Fuentes resulta una autobiografía, con todo lo que ello supone de revelación vital y autojustificación, pero también un apreciable análisis de la sociedad y de la literatura de su tiempo. De este modo se superponen diferentes textos o géneros en uno solo: el de crítica literaria, el estrictamente histórico y el más personal de la biografía del autor. [...] Parece claro que, puestos a realizar un juicio de valor, prevalece sin duda el relato más personal de su propia vida que el resto de discursos que se superponen» (Cáseda 1994, pág. 415). 
de su escritura, la difusión lograda y por haber inaugurado el uso de la prensa para el género autobiográfico.

Vicente Llorens explica así el tipo de relato que consigue el autor de los Recuerdos de un anciano: «Alcalá Galiano fue con los años un converso, un arrepentido, o mejor un desengañado del liberalismo de su juventud. En sus memorias y recuerdos trata en primer término de justificarse, de explicar sus cambios y hasta, sin querer muchas veces, su fracaso. El tono personal, la evocación del pasado ya lejano, con sus toques pintorescos y anecdóticos, añaden atractivo a sus descripciones y relatos; pero el conjunto histórico padece, los contornos de los hechos se desdibujan y sobre todo vacila el criterio político» (1968, pág. 353). Lo que echa en falta el lector preocupado por «el conjunto histórico» y «el criterio político» es, sin embargo, lo que busca ya Alcalá Galiano tímidamente y lo que Mesonero potenciará hasta sus últimas consecuencias: la evocación del pasado nacional difuminando el espíritu partidista gracias a la nostalgia, la amenidad y la viveza en la descripción ambiental (esos «toques pintorescos y anecdóticos»). Éste es precisamente el aspecto que más han destacado los críticos que han analizado esta obra: su tendencia a acogerse a un relato generacional más que a un relato individual, y cómo eso conduce a un estilo cercano al costumbrismo. Así, Francisco Sánchez Blanco cree que en los Recuerdos se pone de manifiesto la tendencia objetivizante que caracteriza a las autobiografías españolas y las hace rehuir la intimidad y la introspección psicológica ${ }^{23}$.

García Barrón, por su parte, dedica un estudio más o menos detallado al costumbrismo en esta obra, para llegar a la siguiente conclusión: «a pesar de que no es la suya una obra estrictamente costumbrista, la más somera lectura de los seis primeros capítulos de Recuerdos de un anciano pone de manifiesto primorosos ejemplos o atisbos de este género. [...] El Alcalá Galiano que nos describe el Cádiz y Madrid de la primera década del siglo XIX, es un hombre plenamente

${ }^{23}$ «Al leer esta obra se tiene la impresión de estar ante un tratado histórico. Sin embargo está escrito con un espíritu muy diferente al de aquellos que querían salvar su fama contando la historia a su manera. Alcalá Galiano quiere contarnos una vida que aún siendo personal sólo es captable teniendo en cuenta el curso de la historia general. La dinámica psicológica, la evolución de las convicciones políticas y las sensaciones personales de triunfo o fracaso son reflejo de los acontecimientos históricos. Alcalá Galiano puede pintar desde la perspectiva del anciano los diversos momentos de una evolución que van desde el entusiasmo juvenil por la revolución democrática hasta una postura escéptica generada por la pérdida de fe en un pueblo que traiciona y abandona repetidamente a sus líderes. Alcalá Galiano logra reflejar en su autobiografía cómo los acontecimientos históricos van modificando su sensibilidad y sus ideas. Pero en el fondo su descripción no está excesivamente individualizada y podría cuadrar a la de cualquier miembro de la primera generación de liberales» (Sánchez Blanco 1987, págs. 637-638). 
familiarizado con el costumbrismo. [...] Así, pues, el autor nos narra con completo conocimiento de la técnica costumbrista los sucesos ocurridos durante sus años juveniles, pero lo hace más de medio siglo después» (1970, pág. 85). De esta forma, García Barrón justifica la imposibilidad de que el autor haya vivido todo cuanto escribe, puesta de relieve por algunos críticos, en virtud de la legítima técnica costumbrista de usar fuentes externas y recursos artísticos en su reconstrucción. Este costumbrismo galianesco -sigue diciendo García Barrón- se plasma en tres facetas, que no están muy lejos de lo que podemos percibir en las Memorias de Mesonero: descripción pictórica del aspecto exterior de Madrid y Cádiz; esbozos detallados del interior de sus viviendas; y bosquejos del vestuario de sus habitantes.

El corolario de este análisis no suele hacerse explícito, pero resulta evidente: se trata del mismo proceso que, en mayor grado, efectúa Mesonero Romanos en las Memorias de un setentón. No obstante, como en el caso de Mor de Fuentes, la evolución hacia, digámoslo así, la despersonalización del relato autobiográfico en favor de la memoria colectiva, sigue sin sofocar el yo por completo. La diferencia entre las dos grandes obras autobiográficas de Alcalá Galiano, las Memorias y los Recuerdos, muestra la clara evolución del género de las memorias políticas a esa otra modalidad que, por decirlo pronto y mal, podemos denominar costumbristas. Pero el cambio experimentado seguía siendo insuficiente, si bien no cabe duda de que fue un estímulo para Mesonero Romanos, que leyó los Recuerdos de un anciano y reflexionó sobre sus enseñanzas literarias, aunque se negó a reconocerse en ese modelo.

En efecto, Escobar y Álvarez Barrientos señalan que Mesonero quiso distanciarse de los Recuerdos de un anciano, rechazándolos como posible precursor por no verlos próximos a su ideal de ocultación del satánico yo y de despolitización $^{24}$; es decir, que para el madrileño las memorias del gaditano seguían siendo más bien una autobiografía, el indeseable escrito de un político que explicaba su carrera otorgándose todo el protagonismo, mientras que él deseaba encarnar el papel de cronista de su tiempo. Mesonero tenía razón, pero seguramente no hacía justicia del todo a Alcalá: al dar tanta importancia a lo que le separaba de él dejaba de lado lo mucho que en los Recuerdos del anciano se avanzaba hacia lo que

${ }^{24}$ «Es significativo que uno de los primeros ejemplos del uso del término autobiografía, en español, aparezca precisamente en el intento de Mesonero de fijar la identidad de sus Memorias. En una carta de 18 de marzo de 1880, de Vicente de la Fuente a Mesonero, el neologismo aparece como un rechazo explícito del concepto expresado por la nueva palabra en contraste con el de memorias. Por lo que se deduce de esta carta en contestación a otra de Mesonero, que desconocemos, éste no quiere que sus Memorias sean tenidas por autobiografía, distinguiéndolas así de los Recuerdos de un anciano, que quiere alejar lo más posible de su propia obra» (en Mesonero 1994, pág. 66). Sobre esta cuestión, véase también el artículo de Escobar (1993). 
serían las Memorias del setentón; tal vez su deseo de marcar distancias provenga en realidad de no querer reconocer una deuda que, sin embargo, existe.

La deuda que sí reconoció el costumbrista madrileño fue la que contrajo con el antecedente más inmediato de sus propias memorias, los Recuerdos literarios. Reminiscencias biográficas del presente siglo del ya mencionado poeta romántico, autor teatral, novelista y político Patricio de la Escosura y Morroch. Esta serie de diez artículos apareció en La Ilustración Española y Americana entre enero y marzo de 1876 , sin que por desdicha fuera nunca coleccionada en volumen, lo que ha minimizado su repercusión. Escosura se propone trazar unas cuantas estampas de su infancia y juventud, orientadas específicamente a retratar a célebres escritores con quienes tuvo trato (Olózaga, Ventura de la Vega, Espronceda, Bretón de los Herreros, Grimaldi), aunque en realidad hay bastante más que semblanzas, ya que incluye vivas descripciones del ambiente literario y político de los estudiantes madrileños en el Trienio y los tres últimos capítulos hablan monográficamente de la sociedad secreta liberal de los Numantinos, en la que tomó parte.

Sabemos que Mesonero leyó estos artículos y que le influyeron en su propio proyecto, como han puesto de manifiesto los críticos: «lo verdaderamente trascendente de los Recuerdos literarios está, creemos, en que quizá sirvieron de acicate, cuando no de orientación, para hacer aparecer el libro tan rico en noticias que es Memorias de un setentón. [...] Todo nos lleva a concluir que Mesonero [...] tenía seguramente pensado y configurado el esquema de su libro mucho antes que Escosura publicara sus Recuerdos literarios, pero era necesario que alguien o algo le estimulara a la publicación, lo que probablemente y sin imaginarlo siquiera logró don Patricio» (Cano Malagón 1988, págs. 41-42). El único testimonio que maneja esta investigadora es el mismo que usan Escobar y Álvarez Barrientos y cuantos otros se han preocupado de esta posible influencia, la carta escrita por Mesonero a Escosura el 13-III-1876 y editada por Manuel Núñez de Arenas (1947). En ella el madrileño confiesa que desde antiguo acariciaba una idea parecida a la que acababa de materializar Escosura. Extracto su parte más sustancial:

[...] este placer [de leer su libro] no es sólo ocasionado por el primor de su narración, sino también, y más principalmente, porque casi contemporáneos y homogéneos con los recuerdos míos hieren unísonos la cuerda de mis sentimientos y de mi imaginación. Hace algún tiempo que aunque embotada ésta y mis sentidos por la edad y los achaques, pero dejando en pie la memoria excepcional que debí a la providencia divina, me propuse consignar en el papel una idea semejante a la de V. en una obra que había de titular Memorias de un setentón [sic] vecino de Madrid, que cuando no deleitar a los lectores, me pro- 
metía hacer que consiguiese, al menos, despertar la curiosidad de los jóvenes que tienen la amabilidad de solicitar mi conversación, y de los pocos viejos que aún quedan entre los que la aplaudían en mis débiles escritos. [...] El plan de mi escrito no había de ser como el de V. el de trazar unas biografías de las personas más o menos interesantes con quien en su agitada vida pudo estar en íntimo contacto; sino el de trazar en rasgos generales el cuadro más o menos detallado de la marcha y vicisitudes de la sociedad, delineando de paso los perfiles de las personas influyentes en ella, y relacionándolas con los sucesos especiales y mis particulares recuerdos de dichas personas [...] Pero, en fin y para concluir esta charla quizás impertinente, diré a V. que por muy imperiosos que fueran mis propósitos de acometer aquella empresa, y por mucho que me los haya recordado y estimulado a llevarla a cabo la grata lectura de los artículos de $\mathrm{V}$. tendré que renunciar a ella porque la edad y los achaques inutilizan mis deseos, y porque, no sabiendo ni pudiendo dictar en toda mi vida, mi embotada pluma y cansada vista se niegan ya a seguir los vuelos de la imaginación (en Núñez de Arenas 1947, págs. 397-398).

Ya sabemos que esa última reserva no se llegó a cumplir, ya que el mismo año 1876 Mesonero dio a luz el primero de los artículos que adelantaban sus Memorias. Es evidente, en cualquier caso, que Mesonero se sintió identificado con la realización de Escosura, entendiendo que era ése el camino que él mismo debía seguir. La propuesta contenida en los Recuerdos literarios tenía dos elementos que congeniaban con las intenciones de Mesonero. Por un lado, el protagonismo del yo quedaba reducido a una mera función de testigo de su tiempo, precisamente de aquellos hechos y personas que con el paso de los años habían adquirido una condición representativa y que eran ya conocidos por el público y suscitaban su curiosidad; es decir, Escosura seleccionaba de su memoria subjetiva lo que también formaba parte de la memoria colectiva, para ofrecer detalles íntimos que nadie más que él conservaba, y desechaba cualquier otro recuerdo que no suscitase la identificación inmediata de los lectores. En segundo lugar, estas memorias se plantean en el ámbito literario, dejando la política en un plano secundario; ésta no parece interesar en sí misma, sino para retratar el tipo de ideas y pasiones que dominaban a aquellos jóvenes escritores evocados, lo que permite un grado de despolitización -que no de desideologización-en el recuerdo del pasado como el que pretenderá Mesonero: la vida literaria y cultural será también el objetivo central declarado por el madrileño.

Hasta aquí el alcance del modelo. Pero la obra de Escosura seguía siendo escasa para lo que Mesonero aspiraba a escribir. En el fragmento reproducido más arriba de la carta, el Curioso Parlante especifica su principal diferencia con lo hecho por aquél: no quería elaborar una colección de semblanzas y episodios sueltos, sino «trazar en rasgos generales el cuadro más o menos detallado de la 
marcha y vicisitudes de la sociedad». De hecho, Mesonero no está pensando en superar a Escosura, sino en superarse a sí mismo, en superar los cuadros costumbristas que le hicieron famoso en favor de una narración que integre el conjunto de la vida social que conoció (ahí es donde resulta determinante el influjo de Galdós y de la novela contemporánea). En la misma línea, en la carta recuerda también a Escosura que, al ser él más viejo, podrá remontarse más atrás en sus recuerdos; y repitiendo una idea que introducirá en el prólogo de sus Memorias, dirá que su «completo apartamiento de la escena pública, aunque colocado por mi posición y por mi carácter en la primera fila de los espectadores» (en Núñez de Arenas 1947, pág. 398) le otorgará una perspectiva más general, mientras que el protagonismo político de Escosura le hace centrarse en un puñado de grandes «personajes históricos, políticos y literarios» (pág. 397). Formula, por tanto, un ideal totalizador y, otra vez, menos político, como su principal aportación respecto a lo que acaba de hacer Escosura.

Los inmediatos modelos de que dispuso Mesonero dibujan, por tanto, una clara línea hacia una mayor integración del punto de vista personal de la memoria subjetiva con una visión histórico-costumbrista que represente, más que una vida particular, una experiencia colectiva ${ }^{25}$. El proceso culmina de forma lógica en las Memorias de un setentón y en el tipo de discurso que he analizado en el apartado anterior a éste; de ahí se difundirá a otros muchos autores durante décadas, como me ocupo de estudiar seguidamente.

\section{LA PROGENIE DEL SETENTÓN}

En el último párrafo de las Memorias, al detenerse en el año 1850 , Mesonero pronostica que «para dar este ambiente de antigüedad a la pintura de los hombres y las cosas más cercanas, y para despertar la curiosidad y simpatía de la generación venidera, no faltará, seguramente, alguna futura y humorística pluma, algún viejo setentón de 1920» (pág. 530). Sin duda no imaginó lo exacto que iba a ser este retórico cierre, ya que en efecto muchos setentones, y en especial en los primeros treinta años del siglo XX, le tomarían la palabra. Es ahora el momento de volver a la idea con que abrí este artículo, con la contundente afirmación de Caballé: «de las memorias publicadas en el XIX, las que indudable-

${ }_{25}$ Un último texto contemporáneo a Mesonero que podría citarse es el de José de Navarrete (1836-1901), Desde Vad-Ras a Sevilla, acuarelas de la campaña de África (1876, reeditado en 1880), unas memorias militares de la guerra de Marruecos que, alejándose de ese modelo inicial, muestran una evidente inclinación hacia contenidos exóticos y costumbristas: crónicas y anécdotas sobre costumbres marroquíes, animados cuadros de la vida militar y unos últimos capítulos que se convierten en descripciones de la feria de Sevilla, de una escena flamenca, etc. 
mente influyeron con más fuerza en su tiempo fueron las de Mesonero [...]. Y ello hasta el extremo de que la excelente acogida crítica y popular obtenida por la obra desde su publicación (1880) motivó el auge del género, aunque también un rápido desgaste, ya vaticinado por Larra mucho antes» (1990, pág. 57). Sin temor a errar puede afirmarse que con las Memorias de un setentón, el género memorialístico español cuenta por primera vez con un clásico, a la vez estímulo y ejemplo. Mesonero significa una nacionalización de un género que se percibía como foráneo, afrancesado; a partir del Curioso Parlante es posible una versión castiza, española, nacional. Para valorar la manera en que se asimiló su magisterio, hay al menos tres criterios:

A) La imitación directa en títulos que contienen la indicación de la avanzada edad del autor y una referencia geográfica es un índice clarísimo del magisterio de Mesonero sobre un modo particular de autobiografía, que pasa por una vinculación explícita a un espacio y una perspectiva desde la vejez. Los títulos que sólo contienen la idea de ancianidad ocupan un lugar secundario en la lista de influencias de Mesonero, ya que se trata de un recurso habitual entre los autobiógrafos, en el que el madrileño había sido precedido por los Recuerdos de un anciano de Alcalá Galiano; en cambio, la concreción exacta de la edad del anciano sí parece una aportación genuina de Mesonero a la tradición autobiográfica española ${ }^{26}$.

${ }^{36}$ Existe un precedente italiano para el título elegido por Mesonero, las Confessioni de un Ottuagenario (1861), de Hipólito Nievo (cit. en Caballé 1991, pág. 144). Sobre la cuestión de los títulos, cf. Fernández (1992, pág. 104). Además de las obras de las que hablaré con algún pormenor en las páginas siguientes, hay una larga e ininterrumpida serie de títulos semejantes en el siglo $\mathrm{XX}$, que indican el arraigo de un tópico. Por ejemplo, Manuel Polo y Peyrolón (1846-1918), escritor y profesor católico conservador, dejó escritas entre 1906-1917 unas voluminosas Memorias de un sexagenario en nueve tomos (uno de sus tomos se titula Memorias de un sesentón), depositadas en la Real Academia de la Historia. Sin particulizar las circunstancias de cada texto, puedo ofrecer la siguiente lista orientativa: Antonio González Curquejo, «Recuerdos de un sesentón de 1858 a 1867. La Avellaneda en Cuba», en Cuba y América (abril 1917); Fernando Piñana, Cielo azul y arena roja. Vida y milagros de los grandes toreros... visto, oido y leido por un abonado cincuentón (1915); Francisco Rodríguez Marín, En un lugar de la Mancha. Divagaciones de un ochentón evacuado de Madrid durante la guerra (1939); Teodoro Llorente Falcó, De mi Valencia de otros tiempos. Memorias de un setentón. (Artículos publicados en «Las Provincias») (1942-1945, 4 vols.); Francisco Puig y Alfonso (1865-1946), Recuerdos de un setentón (1943); Zenón Arámburu (n. 1879), Desterrado de China. Memorias de un misionero octogenario (1960); Julio Carro y Carro, La vida contemporánea vista por un octogenario (1969); Manuel Celaya Cendoya, Fragmentos de la autobiografía de un nonagenario dedicados a una nonagenaria (1970); Domingo José Navarro, Recuerdos de un noventón. Memorias de lo que fue la ciudad de Las Palmas de Gran Canaria al principio del siglo y de los usos y costumbres de sus habitantes (ediciones en 1971, 1991, 1998); Sebastià Gasch, El Molino. Memorias de un setentón (1972); Juan Rico Marlebrera, Memorias de un setentón. De Monóvar a Méjico (1977); Juan Villamaza, Memorias y reflexiones socio-políticas de un septuagenario (1996); Rafael Romero 
B) Las alusiones de los autores en los preliminares de sus libros, en que se suele mencionar la obra de Mesonero Romanos como cumbre inigualable y modelo que autoriza la pretensión del memorialista de turno a contar su vida y su tiempo; en un género en el que se siente siempre la necesidad de justificar por qué se escribe, acogerse a la autoridad del Setentón es frecuente incluso en autobiografías que tienen poco que ver con el estricto modelo representado por él.

C) Un tercer criterio, más difícil de evaluar, es la imitación de la misma fórmula autobiográfica practicada por Mesonero. Es sin duda el influjo más importante, aunque también escurridizo, ya que el modelo de rememoración establecido por las Memorias de un setentón es inestable, se escora con facilidad hacia una reconstrucción histórica que prescinda de elementos autobiográficos, o bien hacia un protagonismo del yo que es ajeno a la práctica de Mesonero, aunque siempre complicado de evitar. A veces, las obras más influidas por el Curioso Parlante no son memorias, sino colecciones de artículos o cuadros sueltos de costumbres, anécdotas e historias de una determinada época y lugar, en las que el narrador se ha neutralizado por completo; en cambio, otras son puras memorias políticas o literarias de tipo personal, pero a las que se ha dado un intenso telón de fondo describiendo la sociedad de su tiempo, que habitualmente sirve para minimizar la exposición de la intimidad del autor ${ }^{27}$.

A continuación, trataré de desglosar en orden cronológico -y sin pretensiones de exhaustividad- las derivaciones más visibles del estilo autobiográfico de

Bonaños (n. 1915), Memorias de un octogenario (1997). La pervivencia de este modelo de referencia se ha extendido también a Hispanoamérica; veánse algunos títulos espigados en bases de datos bibliográficos: Aquileo Sierra, , Vive la vida! Memorias de un cuarentón (Medellín, 1934); Eulogio Rojas Mery (n. 1877), Recuerdos de un joven «octogenario» (Santiago de Chile, 1958); Luis Robalino Dávila, Memorias de un nonagenario (Quito, 1974); José Humberto Quintero (n. 1902), Confidencias de septuagenario (Caracas, 1979); José María Arias Rodríguez, Observaciones de un agricultor octogenario (San José de Costa Rica, 1983); Ricardo Bayona Posada, Recuerdos de un ochentón (Bogotá, 1984); Ángel Miolán, Memorias. Testimonios de un octogenario sobre su vida y la política de su país (Santo Domingo, 1995).

${ }^{27}$ En ese sentido Caballé valora negativamente esta influencia: «en mi opinión, la influencia de las Memorias de Mesonero no es del todo positiva, pese a su carácter canonizador en el desarrollo del género, pues imprimen a las obras posteriores dos rasgos desafortunados: la servidumbre del autobiógrafo al discurso histórico (en la primera mitad del siglo se trataba del sometimiento al discurso político) que, finalmente, resultará coloreado por la vivacidad de la anécdota costumbrista, pero que permanecerá ajeno al desarrollo de la personalidad individual y, en consecuencia, alejado del objetivo primordial de la literatura de índole confesional. En segundo lugar, el anhelo por captar lo pintoresco de los acontecimientos convierte las Memorias de un setentón en una colección de estampas que fácilmente recuerdan al castizo autor de las Escenas matritenses pero que carecen de profundidad narrativa: la visión constructiva y con sentido del pasado no se logra sólo acumulando hechos, solía recordar don Américo Castro» (Caballé 1995, pág. 153). 
Mesonero, dejando claro que cada caso que cite merecería un estudio particular bien matizado, que no es aquí el lugar de hacer.

El primer escritor que aceptó a Mesonero como un clásico y se sintió influido por su proyecto memorialístico fue José Zorrilla (1817-1893), incluso antes de que las Memorias de un setentón se coleccionaran en libro. Zorrilla comparte con Alcalá Galiano, Escosura y Mesonero el ser un anciano escritor de una generación pasada, separado por varias décadas del momento de su gloria literaria. Es poco dudoso que el ejemplo de Mesonero le sirvió de acicate para escribir unos Recuerdos del tiempo viejo que apuntan en su propio título al tópico de la ancianidad, y que fueron empezados a publicar en Los lunes de El Imparcial en octubre de 1879 (recogidos en volumen en 1880 y 1882). Zorrilla lo declara expresamente:

Mis Recuerdos no son, desventuradamente para mí, una obra de cronológica ilación, de continuidad lógica y progresiva, de bien enlazados sucesos, y de uniforme estilo, como las curiosas Memorias de un setentón, del Sr. de Mesonero Romanos, a quien aprovecho esta ocasión para dar gracias por el cariñoso homenaje debido al más fácil de nuestros prosistas, al más ameno y castizo de nuestros narradores, al más cortés de nuestros críticos, y al más exacto pintor de nuestras costumbres. Mis Recuerdos no pueden, ni intentan competir con sus Memorias; y cuando hoy se reducen a libro con una más ordenada forma, aún no pueden parangonarse con aquéllas; elegante y última, pero genuina producción del vigoroso ingenio del Curioso Parlante, en cuya curiosa personalidad prolonga Dios la luz de la inteligencia para gloria y contentamiento de la presenta generación (Zorrilla 1943, II, pág. 1808) ${ }^{28}$.

Las frases del vallisoletano inciden en lo que más preocupaba a Mesonero, y que mencionó en su carta a Escosura, el deseo de conseguir una rememoración completa y unitaria de la vida social que conoció. Zorrilla sigue su ejemplo de escurrir el bulto (el yo) en favor de elementos externos, extrema el carácter literario y apolítico de los recuerdos, pero desde luego hace una obra asistemática, desordenada y desigual, al tiempo que repleta de complejidades psicológicas para nada presentes en el Curioso Parlante ( $c f$. Durán López 1995). La influencia, por tanto, no determina el contenido.

${ }^{28}$ Las Memorias de Mesonero actúan también como fuente histórica. En determinado momento, Zorrilla habla del Liceo de Madrid en la década de 1830 y elude extenderse porque: «...ya ha dicho lo que era, en La Ilustración, el ameno Curioso Parlante don Ramón de Mesonero Romanos; y ante él arría bandera quien en su juventud supo aprovecharse de su picante y donosa crítica, y hoy se complace en hallar una ocasión de darle una prueba de consideración y respeto» (Zorrilla 1943, II, pág. 1749). En otro pasaje explica: «...las mal empedradas calles y peor alumbrados callejones de la villa y corte de entonces, de la cual dan tan exacta idea las Memorias de Mesonero Romanos» (Zorrilla 1943, II, pág. 1810). 
Mario Méndez Bejarano (1923) y alguna que otra fuente citan como obra del clérigo y hebraísta Antonio María García Blanco el siguiente título: Memorias de un ochentón natural de Osuna. En realidad, esa obra apareció impresa en 1887 bajo el nombre de Historia compendiada de una larga vida. Resumen de un siglo $^{29}$, pero el error es comprensible, ya que García Blanco había manejado ese otro título antes de decidirse por no imitar tan abiertamente a Mesonero. Como explica Pascual Recuero (1986), al retirarse a Osuna, el viejo profesor empezó a publicar en 1883 unos artículos en El Ursaonense titulados «Mis primeros recuerdos»; luego se persuadió de que esto podría dar lugar a una obra de más aliento -aquí es donde el modelo de Mesonero parece hacerse presente- y durante los años siguientes redactó unas completas memorias, de la que publicó un capítulo en El Centinela de Osuna en febrero de 1887: allí dice que eran parte de las Memorias de un ochentón, natural de Osuna y vecino de Madrid, por lo que parece que hasta el último momento ése iba a ser el nombre de la obra. En realidad se trata de una rememoración muy centrada en su propia vida, aunque cuajada de anécdotas y noticias históricas del tiempo que le tocó vivir, que es la parte que más acusa el influjo del Curioso Parlante.

Del erudito gaditano Adolfo de Castro y Rossi (1823-1898) hay noticias indirectas, que nos ha transmitido su íntimo amigo Martín de Mora, acerca de su intención de escribir unas memorias semejantes en el último tramo de su vida: «invirtió largo tiempo sin sentir desmayo ni aburrimiento, guiándole el laudable propósito de llevar a las páginas de unas Memorias, desconocidas desgraciadamente, cuantas noticias llegase a adquirir y halló aunque no todas las que se proponía, al lado de mil sucesos y hechos en que aparecía como protagonista o había intervenido durante su vida pública y literaria, a imitación, así me lo había repetido, de las Memorias de un setentón del curioso parlante, el ingenioso y cultísimo D. Ramón de Mesonero Romanos» (en Vallejo Márquez 1997, pág. 54; la cita procede de un artículo de Mora en Diario de Cádiz, 20-X-1912).

Entre 1895-1897 publicó La España Moderna las memorias tituladas Aventuras y desventuras de un soldado viejo natural de Borja, obra de Romualdo Nogués (1824-1899), recogida en volumen en 1897. El título alude una vez más,

${ }^{20} \mathrm{El}$ título completo es: Historia compendiada de una larga vida. Resumen de un siglo. Ipalabra hebrea $]=[$ ?]eleth $=$ Colección. - Miscelánea $=$ Mischlé $=[$ palabra hebrea $]$. Personas, cosas $y$ sucesos que han pasado y yo he visto en el siglo XIX/(desde 1800, en que naci, hasta 1900, en que habré acabado ya). Anécdotas, paradojas, cuentos, sucedidos, vicisitudes, leyes y costumbres religiosas, políticas, familiares, sociales, públicas y privadas, naturales y preter o sobrenaturales, maravillas (MIRABILIA), profecias dignas de saberse y llegar a noticia de todos los españoles. A. $M^{a} G$. B. faciebat. 
meridianamente, a Mesonero. Aunque digresivo y cuajado de anécdotas, el escrito de Nogués se ocupa de sus memorias personales entre 1824-1875, con especial incidencia en su vida militar. Un punto en que se aproxima a Mesonero es en su insistencia en ser un hombre oscuro, lo que sin embargo no le deslegitima para escribir su vida: no denomina memorias a su obra «porque no llegué a personaje», lo más decente que ha presenciado -dice- es la batalla de Vad-Ras, «y no maté ningún moro» Es también significativo que Nogués hubiese escrito años atrás otra obra autobiográfica, Memorias de un coronel (1875-1878), sobre las campañas carlista y norteafricana, de estructura más anecdótica y dispersa, pero que no estuviese dispuesto en esa época a publicarla. Me atrevo a sugerir que su decisión de dar a luz veinte años más tarde su segundo trabajo autobiográfico tiene que ver con la consolidación pública del género que se iniciaba precisamente cuando estaba redactando aquella primera obra.

El escritor y político Eusebio Blasco (1844-1903) también se aproxima mucho al modelo ofrecido por Mesonero, aunque con más presencia del yo y también de la política, en sus Memorias intimas (1904, escritas en 1898), intensa evocación de la vida madrileña entre 1862 y 1868 , centrada en los políticos y los literatos ${ }^{30}$.

José María Puelles y Centeno (n. 1853), médico de Alcalá de los Gazules (Cádiz), escribió unas memorias de su vida, centradas en su participación en la tercera guerra carlista (Recuerdos de mi juventud, 1907, edición corregida en 1911) y afirma en el prólogo que los ejemplos de Mesonero, el general Córdoba y Alarcón, como modelos inimitables, le desanimaban a escribir su propia vida. Su obra no concuerda excesivamente con la fórmula de Mesonero, aunque es significativo el hecho de que en la primera edición acompañe las memorias de otro libro suyo consistente en cuadros de costumbres de ambiente rural gaditano.

Enrique Menéndez Pelayo (1861-1921), en sus Memorias de uno a quien no sucedió nada (1922, escritas hasta poco antes de morir), reserva como primer párrafo -lo que le da gran relieve en un texto sin prólogos- el siguiente pasaje:

3.) «[...] tengo que conversar, contar, como cuentan los viejos al amor del fuego, sus recuerdos de muchachos. Habiendo intervenido directamente, desde la edad de veinte años, en tantas cosas políticas, literarias, teatrales, sociales, y habiendo vivido en mundos y países distintos, las Memorias que estoy preparando, y de las cuales son capítulos sueltos estas conversaciones de ahora, son interesantes, no porque las cuente yo, sino por lo que en ellas cuento. Y si abunda el yo, que siempre parece pretencioso en estos recuerdos, es porque los escribo como testigo o como autor de ellos. Así, pues, perdonadme cuando hable de mí, que al fin y al cabo son éstas Memorias de mi vida y el único privilegio que tenemos los que ya vamos caminando hacia los sesenta es poder hablar por experiencia propia y referir lo que de cerca vieron» (Blasco 1904, págs. 7-8). 
"Cuenta Mesonero Romanos, al principio de sus deliciosas Memorias de un setentón, que él fue una de las primeras víctimas del 2 de Mayo de 1808, en cuyo año se cumplían los cinco de su edad, y refiere, en comprobación de su aserto, cómo, habiendo oído en la mañana del épico día rumor de tropas que avanzaban por la calle, corrió a un balcón para verlas, e hízolo con tal prisa y aturdimiento, que, tropezando en el umbral, causóse una herida en la cabeza. Así yo, a imitación de El Curioso Parlante, aunque con menos fortuna que él, hube de tomar parte, a los seis años de edad, en cierto asalto efectuado el día 24 de Septiembre de 1868» (1983, pág. 127). Es clara la asunción de un modelo, que se muestra además en ese título que incide en el tópico del mero particular, observador de la historia a su alrededor, que ya hemos visto en Mesonero y en otros autores. También estructuralmente la obra se acerca al ejemplo del madrileño: una colección más o menos desordenada de estampas de la vida pública y privada en Santander, en Valladolid y en el entorno madrileño de su adorado hermano Marcelino.

El ingeniero Eduardo Cabello Ebrentz (1865-1957) escribió hacia el final de su vida unas memorias personales que coloca desde el primer párrafo bajo la referencia de Mesonero, única lectura autobiográfica que parece haber interiorizado: «...no es mi propósito el atrevimiento de parodiar las Memorias de un setentón natural y vecino de Madrid, del insigne Mesonero Romanos, si bien de la memoria de un setentón, aunque no de Madrid, surjan, porque nada hay sucedido en el curso de mi vida que pueda interesar a persona a quien no le ligue a mí su afecto, es decir, que le interese el hecho, no en sí, sino por ser mío» (Cabello 1991, pág. 9). Su realización es, en efecto, muy diferente de la de Mesonero, ya que explica su trayectoria personal, centrado en el yo, pero sigue siendo significativo que una obra escrita por alguien que no es profesional de la escritura, a mediados del siglo $\mathrm{XX}$, mantenga todavía el eco del enorme prestigio y penetración alcanzados por las memorias del Curioso Parlante.

Incluso un hombre como Manuel Vigil Montoto (1870-1961), militante socialista asturiano, escribe en los años cincuenta unos Recuerdos de un octogenario (con notas para ayudar a escribir la historia del Movimiento Obrero en la región asturiana, sindical y político, a quien quiera hacerla con más competencia, sin duda, que el autor de este libro), que no fueron publicados hasta 1981 (en una revista, en 1992 en libro). El proceso de escritura de esta obra es ilustrativo de las relaciones que mantiene la autobiografía con la historia: su intención inicial, trabajada desde 1926, era escribir la historia del socialismo en Asturias, pero después de la guerra, sin documentos, decidió que la única manera de reconstruir aquel periodo era a través de la memoria de sus protagonistas, así que pasó de un 
proyecto exclusivamente historiográfico a otro autobiográfico, en el que su vida y la del socialismo asturiano se iluminaban recíprocamente. Ese cambio impuso un nuevo título, que aunque no lo dice evoca a Mesonero Romanos: «Mas en esta forma hecho el libro, ya no es realmente una historia documentada, en una considerable parte, del movimiento obrero asturiano, como pudo ser la primitiva idea, y en este plan colocado, pensé que debía titular estas páginas Recuerdos de un octogenario (con notas [...])» (Vigil Montoto, 1981, pág. 318). Igual que Mesonero ochenta años antes, Vigil había llegado a una solución de compromiso entre el yo y la historia, en la que la perspectiva de un anciano actuaba como catalizador de una memoria colectiva, en este caso no burguesa y nacional, sino de un movimiento obrero local.

Los textos hasta ahora citados son -con la relativa salvedad de Menéndez Pelayo- verdaderas memorias personales con un protagonismo del yo mucho más acentuado que en Mesonero. Es decir, que aunque el madrileño deje su huella en los títulos, en las alusiones directas y en el impulso de dar a luz tales obras, el contagio estructural del concreto formato practicado por él es sólo parcial: un mayor interés por el entorno exterior de la vida. En otras muchas piezas, en cambio, este influjo es más intenso y el precario equilibrio entre los ingredientes de la fórmula se rompe hacia el lado contrario: el interés se desplaza a espacios geográficos periféricos, el contenido autobiográfico se hace más débil y la estructura del conjunto se resiente, hasta el punto de que a veces dejamos de hallarnos ante textos que podamos definir como autobiográficos, sino ante impersonales anecdotarios histórico-costumbristas. La neutralización del yo que inició el Curioso Parlante llega en bastantes de sus seguidores a reducirlo a una mera persona gramatical. Es una evidente evolución, que tiene mucho de disolución, a partir de la sólida estructura aplicada en las Memorias de un setentón, sobre todo en los escritos producidos para la prensa: al contrario que en Mesonero, a menudo no hay previa planificación, sino que de artículo en artículo el autor va produciendo cuadros sueltos de diferentes aspectos, empleando una técnica entre caótica y asociativa, alterando y rectificando el plan según se desarrolla. El efecto Mesonero es mucho más acusado en esta dirección de la literatura española, como paso a ver a continuación.

El periodista de Valladolid José Ortega y Zapata (1824-1903), abuelo de José Ortega y Gasset, fue otro de los ancianos escritores que se decidió a aplicar el ejemplo de Mesonero a su propio espacio geográfico, en unos artículos presididos por el transparente título de Solaces de un vallisoletano setentón, que fue dando a luz en El Norte de Castilla entre 1894-1895 (parte se recogieron en un libro de 1895, y todos ellos por vez primera en 1984). Ortega aumenta el conte- 
nido costumbrista, elimina la parte histórica y reduce al mínimo el elemento autobiográfico. Por lo demás, es muy claro el parentesco con el modelo de Mesonero, además de en el título, en su blando tono nostálgico, todavía más amable, conformista y acrítico que en el caso del madrileño. Un caso prácticamente calcado al del vallisoletano es el del profesor de Salamanca Luis Maldonado de Guevara (1860-1926), que entre 1898-1926 publicó en un buen número de publicaciones periódicas -en particular en El Adelanto de Salamanca- una larga colección de artículos evocadores de su vida y recuerdos en su tierra natal, recogidos en 1986 en el volumen De mis memorias. Estampas salmantinas, aún más deshilvanadas que las de Ortega.

El periodista Juan Valero de Tornos (1842-1905) escribió un libro titulado Crónicas retrospectivas (recuerdos de la segunda mitad del siglo XIX) por Un Portero del Observatorio (1901), colección de artículos que a menudo se cita dentro del género autobiográfico. El prólogo de Jacinto Octavio Picón que lo abre enumera como precedentes del trabajo de Valero de Tornos las obras de García de León Pizarro, Alcalá Galiano, Mesonero, Fernández de Córdoba y Zorrilla. El propio autor indica que está «hecho un Mesonero, aunque valiendo mucho menos» (cit. en Caballé 1990, pág. 57). Tanto en su caso como en el del periodista Genaro Cavestany (n. 1857) nos alejamos en realidad del territorio estrictamente autobiográfico para entrar en una serie de evocaciones de recuerdos históricos y de sucesos y figuras del ambiente de la juventud y madurez de los autores; es como la obra de Mesonero, pero con un narrador neutral que no usa su propia vida como vehículo conductor de la rememoración. Así Cavestany dio a luz sus Memorias de un sesentón sevillano. Colección de artículos publicados en «El Liberal», de Sevilla (1917-1918), sus Memorias de un viejo (1918-1919) y El Bárbaro Morales. Novela histórica sevillana (Continuación de Memorias de un sesentón sevillano (1921).

El médico y político Carlos María Cortezo (1850-1933) escribió en esta misma dirección, aunque con estructura y estilo más divagatorios, Paseos de un solitario. Memorias íntimas. Hombres y mujeres de mi tiempo (1923, 2 vols.). El mismo año apareció el heterogéneo y abigarrado volumen del abogado y dramaturgo José del Castillo y Soriano (1849-1928) titulado De mi paso por la vida. Notas varias; la justificación de este libro parece calcada de la de Mesonero Romanos, proclamando su valor como testigo de su tiempo a la vez que su insignificancia personal ${ }^{3 !}$. El autor usa su vida como eje para ir enlazando noticias muy

31 «Nada hay, en mí, de relieve propio; pero quizás explique y justifique la publicación de estas Notas la circunstancia de haber sido testigo, durante mi larga vida, de muchos e importantísimos sucesos. La excelencia del lugar, desde donde están hechas mis observaciones, me ha permitido reprodu- 
desiguales acerca de la historia del país y de otra infinidad de asuntos (desde la lista de las personas que vivían en su calle hasta la de los sucesivos ministros de la Restauración) y rehúye siempre todo lo que sea personal; una segunda parte del volumen se dedica en exclusiva a la Asociación de Escritores y Artistas, de la que Castillo fue dirigente.

Emilio Gutiérrez-Gamero (1844-1936), político y escritor, publicó entre 1925-1936 seis volúmenes de un libro titulado genéricamente Mis primeros ochenta años (memorias). Los tomos II-VI surgieron del inesperado éxito del primero, no estaban previstos, y se titulan respectivamente lo que me dejé en el tintero, La España que fue, Clío en pantuflas, El ocaso de un siglo y Gota a gota el mar se agota (todos fueron publicados en un único volumen en 1948 y 1962). El proyecto del autor es similar al de Mesonero: evoca la vida española desde sus primeros recuerdos en adelante, mezclando una vaga progresión cronológica con otra temática y asociativa, combinando los papeles de testigo y de protagonista, pero más de lo segundo que de lo primero. El primer tomo estaba más interesado en la política, mientras que los siguientes amplían su campo de intereses al conjunto de la vida social. También el médico Antonio Espina y Capo (1850-1930) escribió en cuatro volúmenes la obra 1850 a 1920. Notas del viaje de mi vida (1926-1929), donde una vez más se expresa el deseo de acumular todos los recuerdos vividos, interesándose por el entorno antes que por el propio yo y cayendo en el análisis histórico y en el anecdotario ${ }^{32}$.

De estructura algo más acabada se leen las Memorias de un bilbaíno. 1870 a 1900 de José Orueta (1866-1934), publicadas en 1929 (reediciones en 1952,

cir con fidelidad y pormenor de detalle lo que a otros, aun mirando hacia el mismo sitio que yo, la mayor distancia y los obstáculos que los separaban del motivo de sus investigaciones no han permitido que las realizaran con la eficacia debida. Mi voluntad y mi perseverancia han hecho, en el transcurso de no pocos años, gran acopio de sucesos, nombres, fechas, efemérides, consideraciones y curiosidades de utilidad que acaso constituyan fuente de conocimiento en ocasiones determinadas. No me es lícito cegar dicha fuente, por el temor de que se juzgue exhibición personal lo que no es más que modesto propósito de coleccionar noticias y datos de algún interés» (Castillo y Soriano 1923, pág. 5).

32 «El orden será, en lo posible, de tipo cronológico, pero los hechos irán formando, a la manera de los personajes de un cuadro, grupos más o menos relacionados entre sí, y unas veces tal vez resulten cuadros, otras el apunte de cartera, en otros momentos bocetos de un cuadro que no se ha pintado; con carácter histórico, o como narraciones de amena conversación o relatos escogidos en tertulias, teatros o academias, pero todo visto y algunas veces siendo uno de tantos que tomaron parte en el hecho. También he de advertir que en este libro lo principal de él, sobre todo en las dos primeras decenas, se referirá a Madrid, porque entonces no se viajaba como ahora [...]; por tanto, cada decena irá precedida de una reseña breve del Madrid de la época a que se refieren los años, porque no hay que dudar que el medio ambiente es el decisivo en todos los sucesos de la vida del hombre y de los pueblos» (Espina 1926, págs. 10-11). 
1962 y 1993). Con el mismo grado de despolitización y de acrítica nostalgia que aplican la mayoría de los seguidores de Mesonero, traza una colección muy variada de estampas de su infancia y juventud en Bilbao, con escenas y figuras de la vida de la ciudad. Como el Curioso Parlante, pide disculpas por lo que tenga que hablar de sí mismo: «Si en gran parte estas memorias pueden parecer algo como una autobiografía, debo advertir que al relatar mi modesta vida íntima, mezclada en ellas, lo hago sólo como el mejor método o plan aplicable a tan variado y heterogéneo surtido de recuerdos, bastante difíciles de ordenar de otra manera. Pido por ello perdón anticipado a quien lea y pueda creer que encierra petulancia o vanidad, con empeño de hablar de mí mismo» (Orueta 1993, págs. 29-30).

Otro caso es el del sevillano Luis Montoto (1851-1929) en sus dos libros «En aquel tiempo...» (1929) y Por aquellas calendas (1930), ambos subtitulados Vida y milagros del magnífico caballero Don Nadie, acogiéndose a los tópicos del tiempo lejano y de la irrelevancia del autor, comunes, como hemos visto, en esta tradición literaria. La combinación de lo personal, lo histórico y lo costumbrista al rememorar la vida cultural y literaria de Sevilla se aproxima también mucho en este caso a la que vemos en Memorias de un setentón.

Algo menos de autobiográfico tiene José Balcázar Sabariegos, escritor y catedrático de instituto que se interesó por una época de la vida que le permitía el necesario distanciamiento cronológico en sus Memorias de un estudiante de Salamanca (1935), anecdotario costumbrista que lleva el subtítulo expresivo de Notas de la vida escolar salmantina de fines del siglo pasado.-Cómo pensaban y escribían los sabios de entonces.- Intimidades de «El Imparcial», el gran diario madrileño, en la época de su mayor apogeo.- La extraordinaria valía de Ortega Munilla.-Viajes.-Anécdotas, observaciones, relatos, refranes en acción y episodios políticos. Alterna evocaciones de la vida estudiantil y periodística en Salamanca y Madrid, y pequeños detalles de su vida privada.

El periodista Luis Seco de Lucena (n. 1857) escribió Mis memorias de Granada (1857-1933) (1941), donde sobre un vago hilo autobiográfico que sólo se mantiene en los primeros capítulos elabora una abigarrada colección de temas granadinos de su tiempo, aprovechándose de su tarea como responsable del diario El Defensor. El abogado y periodista Tomás Caballé y Clos (1870-1961) aplicó este mismo modelo a su ciudad natal, Barcelona, y a su doble condición profesional en unos libros titulados Barcelona de antaño. Memorias de un viejo reportero barcelonés (1944) y La criminalidad en Barcelona. Funcionamiento de la Audiencia Provincial Barcelonesa de 1885 a 1908. 21 procesos célebres. Memorias intimas de un abogado criminalista y reportero (1945). 
Póstumas se publicaron las que son quizá las últimas memorias de gran aliento que reproducen esa voluntad de totalizar un entorno social a través del testimonio personal de un viejo, y de que ese entorno represente la marcha colectiva de la nación. Me refiero a Setenta años de periodismo. Memorias (1949-1952, 3 vols.) del periodista y político conservador Alfredo Escobar y Ramírez (1857-1949), donde su trayectoria profesional se combina con infinidad de semblanzas de personajes literarios y políticos, evocaciones de la vida madrileña y la historia general y particular desde 1860 en adelante ${ }^{33}$.

El segundo de los libros recién citados de Tomás Caballé nos conduce a otra línea de derivación de esta clase de textos, las memorias profesionales, otra forma de estructurar la conciencia histórica colectiva, no a través de una identidad nacional, sino de un más limitado espíritu corporativo. Aunque el eje de interés sea diferente y más corto, el enfoque es similar. Así vemos cómo Casto Barbasán Lagueruela (1857-1924) da a la imprenta sus Memorias de un defensor (1897, 2 vols.) para relatar una larga experiencia como abogado castrense, tanto desde el punto de vista teórico como a través de doce casos en los que participó y que son el objeto principal de su libro. Los términos en que presenta su proyecto son próximos a los que ya hemos visto en Mesonero: «Yo me propongo entregaros mi experiencia personal, buena o mala, tuerta o derecha: hacer sentir mis impresiones, transmitir mis juicios sobre las personas, sobre los hechos y sobre las cosas; trazar, en una palabra, una serie de cuadros, todo lo animados que yo sepa hacerlos, reproduciendo, en lo posible, la escena en que fui actor» (Barbasán 1897, t. I, pág. 3).

El actor y autor teatral Vicente García Valero (1910-1923) publicó entre 1910-1923 seis series de anécdotas y recuerdos personales del mundo teatral, previamente incluidas en El Heraldo, bajo diversos títulos ${ }^{34}$. El formato periodís-

${ }^{33}$ Este modelo de rememoración autobiográfica, anecdótica y costumbrista parece haber declinado mucho en la segunda mitad del siglo XX, aunque no es imposible citar casos tan recientes como el de José Alfaro López (n. 1887), Madrid. Primera década del siglo XX. 1901-1910 (1979), que mantiene viva esa manera de gestionar los recuerdos de un tiempo pasado.

${ }^{34}$ Crónicas retrospectivas del Teatro por un cómico viejo (1910); Memorias de un comediante. Nueva serie de crónicas retrospectivas del teatro: historias, costumbres, anécdotas, sucedidos, leyendas y cuentos (1911); Dentro y fuera del teatro. Crónicas retrospectivas, historias, costumbres, anécdotas y cuentos (1913); Páginas del pasado. Reseñas retrospectivas del Teatro.- Crónicas macabras.- Leyendas interesantes. - Cuentos morales.- Crítica. - Anécdotas, sucedidos y antiguallas verídicas (1915); Relatos de un vejancón. Serie 50. Narraciones estupendas.- Crónicas y reseñas.- Crítica.Costumbres rurales.- Casos grotescos.- Historias interesantes.- Cuentos alegres (1919); El sexto todo lo charla. Historias del teatro.- Vida y hechos de comediantes.- Sucedidos de la farándula.- Biografías y cuentos.- Crítica.- Reseñas (1923). El vejancón de la quinta serie parece un lejano eco del setentón de Mesonero. 
tico resta cualquier clase de unidad a estos recuerdos, que tienen ya muy poco de autobiográfico, aunque es la mirada del autor (testigo o simplemente hombre de teatro informado, en menos ocasiones protagonista) la que marca el tono y unifica tan variopintos escritos. En la misma línea que García Valero escribió el periodista y autor teatral malagueño Francisco Flores García (1844-1917), que dio a luz Memorias íntimas del Teatro (1910?), Recuerdos de la Revolución (Memorias intimas) (1913) y El Teatro por dentro. (Recuerdos e intimidades) (1914), volúmenes de artículos con recuerdos políticos y teatrales, según los casos, y diverso grado de autobiografismo.

El periodista y funcionario de prisiones José Millán Astray (1850-1923) también escribió unas Memorias (1918-1919, 2 vols.) profesionales, parecidas a las de Barbasán, en este caso centradas en su empleo de director de las cárceles de Madrid y Barcelona: consisten en una larga colección de casos criminales que conoció entre los reclusos a su cuidado, narrados en estilo ameno y novelesco. También puede considerarse como un anecdotario profesional el libro Palique diplomático. Recuerdos de un embajador (1923-1928, 2 vols.), de Wenceslao Ramírez de Villa-Urrutia (1850-1933), donde se vuelcan las experiencias de este político como representante español en diversos países del mundo. El militar y periodista Narciso Amorós Vázquez de Figueroa (1853-1929) publicó Intendencia e intervención. Páginas autobiográficas, por Narciso Amorós, intendente de ejército (1925), donde reconstruye su vida en el ejército en relación con el ramo de intendencia del que se ocupó muchos años, sin interesarse en ningún otro aspecto de su vida o de la vida social a su alrededor.

El abogado conservador S. Julio de Saracíbar (n. 1872), empleado de la Cámara Alta, escribió sus recuerdos profesionales de esa institución en el libro Del Senado que desapareció. Memorias de un funcionario senatorial, ya casi sesentón (1897-1931) (1932). Son unas memorias configuradas como un centón de anécdotas escritas en estilo evocador y jocoso, asuntos curiosos ocurridos durante su etapa allí. Saracíbar, como el otro Setentón que le precedió en el uso de la pluma, se siente incómodo ante el satánico yo: «Es muy difícil, casi imposible, cuando se redactan unas Memorias como las presentes, que quien las escribe, al relatar todo aquello que ha visto o en que ha intervenido [...], no haga a ratos su autobiografía, aun sin quererlo. Sabía yo de antemano que corría este riesgo, y no quise, sin embargo y desde un principio, trazarme, rehuyéndolo, una línea divisoria entre uno y otro campo, para no pasar de ella, seguro como estaba de que tendría forzosamente que atravesarla con frecuencia» (1932, págs. 173-174). 
Adelardo Ortiz de Pinedo (n. 1859), Cuarenta años de cazador. Memorias de caza (1919), hace unas memorias no dedicadas a un oficio, sino a una afición deportiva: desarrollan los recuerdos del autor y todas sus experiencias en bloques temáticos referidos a los distintos aspectos de la caza, con gran cantidad de anécdotas y curiosidades. Dedicado al mundo teatral que conocieron tanto él como su esposa Loreto Prado, el actor Enrique Chicote (1870-1958) publicó en 1944 una autobiografía, que es también un amplio y variopinto anecdotario del mundo de la escena española, con el título de La Loreto y este humilde servidor. (Recuerdos de la vida de dos comediantes madrileños). Por último, para no avanzar más en el siglo XX, ya que las memorias profesionales de estas características han seguido produciéndose, citaré el caso de Juan Ríos Sarmiento, Recuerdos de un magistrado español (1956), donde de una manera temática y no cronológica, espiga un gran número de pequeños asuntos de la vida cotidiana de un juez.

En conclusión, se puede afirmar que el modelo memorialístico de Mesonero ha tenido un importante número de derivaciones: en principio su deseo fue recuperar la historia nacional a través de Madrid; los autores que le siguieron aplicaron su modelo a muchos otros espacios geográficos más localistas. Pero los elementos de identificación del escritor y el lector decimonónico de clase media no se agotaban en la historia nacional y en la patria chica, sino que la cohesión de la identidad burguesa en esa época mesocrática radica en otros gregarismos que no son sólo los geográficos, sino más bien los que se asientan en un espíritu de clase o corporativo: así surgieron buen número de memorias profesionales, en las que el protagonismo es para un oficio concreto, siempre propio de la clase burguesa. En la misma línea, hubo memorias asociadas a instituciones concretas, a edificios incluso, a sociedades de todo tipo, a partidos políticos... Se trata de textos casi siempre poco autobiográficos, a menudo de estructura anecdótica, una suma de sucesos relativos a la experiencia del autor en el oficio, que en ocasiones adoptan una disposición temática en vez de cronológica ${ }^{35}$, o que se convierten en una colección de relatos casi independientes (son los casos de Millán Astray y Barbasán Lagueruela). Así pues, el prisma costumbrista y anecdótico que Mesonero aplicó con un afán de totalización dejó infinidad de herederos atomizados en decenas de lugares, profesiones y grupos, cuya mayor frecuencia se registra en la segunda y tercera décadas del XX; a mi juicio, esa floración de

${ }^{35}$ La citada obra de Juan Ríos Sarmiento, por ejemplo, contrapone memorias a autobiografía, para rechazar esta última porque el autor «hablando de sí mismo [...] aniquila o rebaja la enjundia de los hechos que relata, cuya verdadera sustancia no llega a los lectores. [...] Pensando en esto, decidí que lo esencial de mi narración fuera la anécdota, y que yo hablara de mí lo menos posible, únicamente para servir de engarce entre las anécdotas, que serán lo interesante para el lector» (1956, págs. 5-6). 
obras -casi siempre menores, de escasa calidad y poca repercusión- se debe a la dirección impresa en buena parte de la autobiografía española por las Memorias de un setentón, que actúan como modelo y síntesis última de esta fórmula tan ajustada a la mentalidad de la burguesía en el modo que ésta tiene de vertebrar un cuerpo social y casi siempre en su vertiente más conformista y conservadora.

\section{BIBLIOGRAFÍA CITADA}

ÁLVAREZ BARRIENTOS, Joaquín, 1995. «Las Memorias de un setentón de Ramón de Mesonero Romanos y su relación con el género novelístico», Siglo diecinueve (literatura hispánica) $\mathrm{n}^{\circ} 1$, págs. 29-49.

BARBASÁN LAGUERUELA, Casto, 1897. Memorias de un defensor, por D. Casto Barbasán Lagueruela, capitán de infantería, exprofesor de la Academia General Militar y de la de Infantería, profesor auxiliar de la Escuela Superior de Guerra y director de la revista «Estudios Militares», Madrid, Imprenta del Cuerpo de Artillería (2 vols.).

BLASCO, Javier, 1993. «Autobiografías y memorias en España», en Ricardo GULLÓN (dir.), Diccionario de literatura española e hispanoamericana, Alianza Editorial, Madrid, t. I, págs. 110-117.

BLASCO SOLER, Eusebio, 1904. Obras completas de Eusebio Blasco. Tomo IV. Memorias íntimas, Madrid, Librería Editorial de Leopoldo Martínez.

CABALLÉ, Anna, 1990. «Tradición y contexto en el memorialismo decimonónico», en Félix MENCHACATORRE (ed.), Ensayos de literatura europea e hispanoamericana, Universidad del País Vasco, págs. 53-59.

- 1991. «Memorias y autobiografías en España (siglos XIX y XX)», Anthropos Suplemento 29, págs. 143-169.

- 1995. Narcisos de tinta. Ensayo sobre la literatura autobiográfica en lengua castellana (siglos XIX y XX), Madrid, Megazul.

- 1998. «Memorias y autobiografías en la literatura española del siglo XIX», en Leonardo ROMERO TOBAR (coord.), Historia de la literatura española. Siglo XIX (II), Madrid, Espasa-Calpe, § 4.1, págs. 347-363.

CABELLO EBRENTZ, Eduardo, 1991. Memorias de un ingeniero del siglo XIX: Eduardo Cabello Ebrentz (Artífice del Puerto de Vigo), ed. de Amador 
MONTENEGRO, Madrid, Colegio de Ingenieros de Caminos, Canales y Puertos.

CANO MALAGÓN, María Luz, 1988. «Los Recuerdos literarios de Escosura: otras memorias del siglo XIX», Castilla $\mathrm{n}^{\circ} 13$, págs. 35-42.

CÁSEDA TERESA, Jesús, 1994. Vida y obra de José Mor de Fuentes, Monzón, Centro de Estudios de la Historia de Monzón.

CASTILlO Y SORIANO, José, 1923. De mi paso por la vida. Notas varias, Madrid, Tip.-Lit. A. de Ángel Alcoy.

DURÁN LÓPEZ, Fernando, 1995. «Los Recuerdos del tiempo viejo de José Zorrilla: autobiografía del hombre, memorias del poeta», en Javier BLASCO PASCUAL, Ricardo de la FUENTE BALLESTEROS y Alfredo MATEOS PARAMIO (eds.), Actas del Congreso sobre José Zorrilla. Una nueva lectura. Valladolid, 18-21 de octubre de 1993, Valladolid, Fundación Jorge Guillén - Universidad de Valladolid, págs. 291-298.

- 1996. Edición de Manuel José QUINTANA, Memoria del Cádiz de las Cortes, Cádiz, Publicaciones de la Universidad de Cádiz.

- 1997. Catálogo comentado de la autobiografía española (siglos XVIII y $X I X)$, Madrid, Ollero \& Ramos, Editores.

- 1998. «Autobiografías de un hebraísta decimonónico: Antonio María García Blanco», en Javier MARTÍN CASTELLANOS, Fernando VELÁZQUEZ BASANTA y Joaquín BUSTAMANTE COSTA (eds.), Estudios de la Universidad de Cádiz ofrecidos a la memoria del profesor Braulio Justel Calabozo, Cádiz, Servicio de Publicaciones de la Universidad de Cádiz, págs. 355-363.

- 1999. «Adiciones al catálogo de la autobiografía española en los siglos XVIII y XIX», Boletín de la Unidad de Estudios Biográficos $n^{\circ} 4$, págs. 73-98.

ESCOBAR, José, 1993. «Las Memorias de un setentón, de Mesonero Romanos, en la literatura de su tiempo», en De místicos, mágicos y románticos. Homenaje a Ermanno Caldera, Messina, Armando Siciliano Editore, págs. 269-287.

ESPINA Y CAPO, Antonio, 1926. 1850 a 1920. Notas del viaje de mi vida. 1850 a 1860. Ante mis libros y mis recuerdos, Madrid, Calpe. 
FERNÁNDEZ, James D., 1991. «Textos autobiográficos españoles de los siglos XVIII, XIX y XX. Bibliografía», Anthropos nº 125, págs. 20-23.

- 1992. Apology to apostrophe. Autobiography and the rhetoric of self-representation in Spain, Durham - Londres, Duke University Press.

GARCÍA BARRÓN, Carlos, 1970. La obra crítica y literaria de Don Antonio Alcalá Galiano, Madrid, Gredos.

GIL NOVALES, Alberto, 1991. Diccionario biográfico del Trienio Liberal, Madrid, El Museo Universal.

LÁZARO CARRETER, Fernando, 1983. «Santa Teresa de Jesús, escritora (el Libro de la Vida)», Actas del Congreso Internacional Teresiano, Salamanca, Universidad de Salamanca, t. I, págs. 11-27.

LEJEUNE, Philippe, 1971. L'autobiographie en France, París, Librairie Armand Colin.

LLORENS, Vicente, 1968. Liberales y románticos. Una emigración española en Inglaterra (1823-1834), Madrid, Castalia.

MÉNDEZ BEJARANO, Mario, 1923. Diccionario de escritores, maestros y oradores naturales de Sevilla y su actual provincia, Sevilla, Tipografía Gironés.

MENÉNDEZ PELAYO, Enrique, 1983. Memorias de uno a quien no sucedió nada, ed. de Benito MADARIAGA, Santander, Ediciones Librería Estudio.

MESONERO ROMANOS, Ramón de, 1994. Memorias de un setentón, natural y vecino de Madrid, ed. de José ESCOBAR y Joaquín ÁLVAREZ BARRIENTOS, Madrid, Castalia - Comunidad de Madrid.

MOR DE FUENTES, José, 1957. Bosquejillo de la vida y escritos de D. José Mor de Fuentes, delineado por él mismo, en Miguel ARTOLA (ed.) Memorias de tiempos de Fernando VII, Madrid, Ediciones Atlas (BAE 97), págs. 373-428.

NÚÑEZ DE ARENAS, Manuel, 1947. «Genésis de unas memorias. Una carta inédita de Mesonero Romanos», Bulletin Hispanique XLIX, nos 3-4, págs. 395-399.

ORUETA, José de, 1993. Memorias de un bilbaino. 1870 a 1900, Bilbao, El Tilo. 
PASCUAL RECUERO, Pascual, 1986. Antonio María Garcia Blanco y el hebraísmo español durante el siglo XIX, Granada, Universidad de Granada.

PÉREZ ESCRICH, Enrique, 1864. El frac azul. Episodios de un joven flaco, Madrid, Establecimiento tipográfico-literario de Manini Hermanos.

RÍOS SARMIENTO, Juan, 1956. Recuerdos de un magistrado español, Barcelona, Editorial Juventud.

SÁNCHEZ BLANCO, Francisco, 1983. «La concepción del yo en las autobiografías españolas del siglo XIX: De las vidas a las memorias y recuerdos», Boletín de la Asociación Europea de Profesores de Español XV, n² 29, págs. 39-46.

- 1987. «Autobiografía y concepción del yo desde Mor de Fuentes a Ramón y Cajal», Revista canadiense de estudios hispánicos n 11, págs. 633-644.

SARACÍBAR, S. Julio de, 1932. Del Senado que desapareció. Memorias de un funcionario senatorial, ya casi sesentón (1897-1931), Madrid, Imprenta Julio Cosano.

VALLEJO MÁRQUEZ, Yolanda, 1997. Adolfo de Castro (1823-1898). Su tiempo, su vida y su obra, Cádiz, Cátedra Adolfo de Castro.

VIGIL MONTOTO, Manuel, 1981. Recuerdos de un octogenario, ed. de Aurelio MARTÍN NÁJERA y Antonio GONZÁLEZ QUINTANA, en Estudios de Historia Social, $\mathrm{n}^{\text {os }} 18-19$, págs. 311-466.

ZORRILLA, José, 1943. Obras completas, ed. de Narciso ALONSO CORTÉS, Valladolid, Librería Santarén. Los Recuerdos del tiempo viejo en t. II, págs. 1729-2103. 